Florida International University FIU Digital Commons

\title{
Counter-monumentalism in the Search for American Identity in Hawthorne's The Scarlet Letter \& The Marble Faun
}

Carmen Mise

Florida International University, cmise001@fiu.edu

DOI: $10.25148 /$ etd.FIDC000114

Follow this and additional works at: https://digitalcommons.fiu.edu/etd

Part of the English Language and Literature Commons

\section{Recommended Citation}

Mise, Carmen, "Counter-monumentalism in the Search for American Identity in Hawthorne's The Scarlet Letter \& The Marble Faun" (2015). FIU Electronic Theses and Dissertations. 2186.

https://digitalcommons.fiu.edu/etd/2186 


\title{
FLORIDA INTERNATIONAL UNIVERSITY
}

Miami, Florida

COUNTER-MONUMENTALISM IN THE SEARCH FOR AMERICAN IDENTITY IN HAWTHORNE'S THE SCARLET LETTER \& THE MARBLE FAUN

\author{
A thesis submitted in partial fulfillment of \\ the requirements for the degree of \\ MASTER OF ARTS \\ in \\ ENGLISH \\ by
}

Carmen Mise 
To: Dean Micheal R. Heithaus

College of Arts of Sciences

This thesis, written by Carmen Mise, and entitled, Counter-monumentalism in the Search for American Identity in Hawthorne’s The Scarlet Letter \& The Marble Faun, having been approved in respect to style and intellectual content, is referred to you for judgment.

We have read this thesis and recommend that it be approved.

Ana Luszczynska

Nathaniel Cadle

Bruce Harvey, Major Professor

Date of Defense: June 30, 2015

The thesis of Carmen Mise is approved.

Dean Micheal R. Heithaus

College of Arts and Sciences

Dean Lakshmi N. Reddi

University Gradute School

Florida International University, 2015 


\section{DEDICATION}

Para mis padres.

No hay suficiente palabras para describir cuanto los quiero.

Gracias por ser como son, por ser indudablemente los mejores papas que pueden existir. 


\section{ACKNOWLEDGMENTS}

There are a number of people without whom this thesis might not have been written, and to whom I am greatly indebted.

I first wish to thank the members of my committee for their support, guidance, and patience. Dr. Ana Luszczynska for her support and encouragement. Dr. Nathaniel Cadle for his insightful and thorough feedback. Finally, I would like to thank my thesis

director, Dr. Bruce Harvey. From the very beginning he had faith in this thesis. His reassuring and inspiring words, especially during dark moments, helped guide me through the end.

I would also like to acknowledge the faculty at the FIU English Department. Thank you for a rewarding and most importantly unforgettable undergraduate and graduate experience. You have filled me with a substance that is everlasting, and in many ways you shaped the way I see the world. Thank you.

To my friends and family. The best friends and family I could ever ask for, want, or need. Thank you for your prayers, your words of encouragement, strength and wisdom, the endless revisions and honest criticism, the late night talks and texts, the shoulders to cry on, the drunken nights, the coffee, the truth, the love. 


\begin{abstract}
OF THE THESIS
COUNTER-MONUMENTALISM IN THE SEARCH FOR AMERICAN IDENTITY IN

HAWTHORNE'S THE SCARLET LETTER \& THE MARBLE FAUN
\end{abstract}

by

\title{
Carmen Mise
}

Florida International University, 2015

Miami, Florida

\section{Professor Bruce Harvey, Major Professor}

This study examines the crisis of identity the United States was experiencing in the nineteenth-century through two of the major literary works of Nathaniel Hawthorne, The Scarlet Letter and The Marble Faun. Hawthorne, who lived through this crucial and important developmental period, was concerned as to what this identity would be, how the United States would shape and define itself, and what its future would be if this identity was malformed. In addition, this study will look at counter-monuments as argued by James E. Young in his essay “The Counter-Monument: Memory against Itself in Germany Today” to expand on these issues of identity. If according to Young, the ideal goal of the counter-monument is "not to remain fixed but to change," one can conclude that Hawthorne understood that national identity must be fluid; otherwise, the nation would crumble under the pressure and force of change. 


\section{TABLE OF CONTENTS}

CHAPTER

PAGE

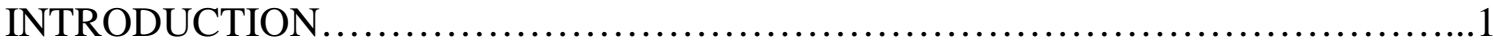

CHAPTER I: CIRCUMSTANCE, CHOICE \& CHANGE: THE PATH TO PRESERVING THE NATION IN NATHANIEL HAWTHORNE'S THE MARBLE

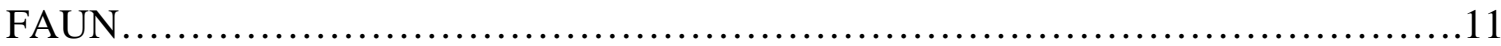

CHAPTER II: NATHANIEL HAWTHORNE'S THE SCARLET LETTER: THE COUNTER MONUMENTALITY OF TEXT IN THE SEARCH FOR NATIONAL IDENTITY .........................................................................

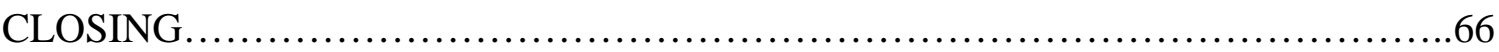

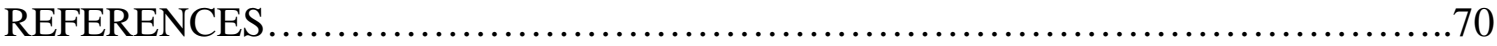




\section{INTRODUCTION}

\section{Identity \& Collective Memory}

French sociologist Maurice Halbwachs, widely acknowledged as the founding father of social memory studies, asserts in The Collective Memory, "We are but an echo" (140). In other words, we assume certain beliefs to be our own, when in fact external forces have shaped them, and as such, a group’s identity begins to take form. A social group’s identity is constructed with narratives and traditions that are created and subsequently passed down to members as a sense of community. The social group may be a small, cohesive unit, like a family. The social group may be what Benedict Anderson calls an "imagined community” that is defined by mediated nationalism. Regardless of the size and complexity of the social group, the group needs to construct and maintain an identity that unites its members. Constructing or maintaining an identity can be done with stories (written and/or oral), artifacts, food and drink, symbols, traditions, images, and music that form the ties that bind members together.

In theory, the formation and maintenance of this collective identity should be a seamless process, yet concerns with this theory of collective identity arise almost immediately. Sometimes, the constructed identity might be flawed from inception. In other instances, the constructed identity is not inclusive of race, gender, or religion. At times, the members of the community are reluctant to change the constructed identity when faced with a need to. But if we look at the monument, the one form of remembrance that most communities have used at one point or another for commemoration, we are able to determine how well or how poorly a community has managed their process of identity formation. 
A monument, according to the Oxford English Dictionary, is "a building, structure, or site that is of historical importance or interest.” It would be appropriate to add to this established definition that monuments can also be viewed as society's recognized form of expression and representation of memory that is worthy of remembrance. In marking certain aspects of a culture's past worthy of remembrance, monuments establish shared ideals and define shared histories. Routinely, monuments consist of markers erected by a community who want to present a narrative of the past for present and future generations.

However, this same sense of timelessness is the very aspect that sparks many of the arguments about them. If sites of collective memory such as monuments serve as a type of public civic lesson, then understanding how they change over time offers unique insights into changing conceptions of nationality, culture, society, and global collective consciousness. Consequently, monuments offer an important gauge of who was and who was not deemed worthy of remembrance or commemoration, or more importantly, how a nation's collective memory or identity evolves over time.

\section{Counter-Monuments Defined}

An artistic movement titled anti-monumentalism, also called countermonumentalism, coined by James E. Young in the 1990s in correlation with debates on contemporary monument concepts of the Holocaust, attempts to challenge the established definition and meaning of monuments. As Young details in his essay "The CounterMonument: Memory against Itself in Germany Today,” these debates stem from Holocaust commemorative work in Germany, which he describes as "a tortured, selfreflective, even paralyzing preoccupation. Every monument, at every turn, is endlessly 
scrutinized, explicated, and debated" (269). These debates stem from the controversial way history is traditionally remembered on the side of the victorious versus the defeated. After all, the victors are known for erecting monuments to remember their achievements, yet this is seemingly harder for Germany as Young points out: "Only rarely does a nation call upon itself to remember the victims of crimes it has perpetrated" ("The CounterMonument” 270). Thus, how does a nation choose to remember the atrocities committed by and to its own people? Most importantly, how does a government? As such, for Germany, the task of remembrance remains "torn and convoluted” ("The CounterMonument” 271). Germany is "tortured by its conflicted desire to build a new and just state on the bedrock memory of its horrendous crimes," Young argues ("The CounterMonument” 271). Germany's history and continuing debates on commemoration have given rise to the building of counter-monuments.

Counter-monumentalism argues that monuments can paradoxically disengage us and inevitably act like a buffer for history. More importantly, they can numb us rather than help us identify ourselves with the past. It is almost as if memory becomes entrusted to the monument rather than to us; hence, the existence of the monument takes over the responsibility of remembering, therefore leaving us as passive spectators. Young makes the point that, "rather than embodying memory, the monument displaces it altogether, supplanting a community’s memory work with its own material form” (“The CounterMonument" 277). The ideal goal of the counter-monument according to Young is "not to console but to provoke; not to remain fixed but to change; not to be everlasting but to disappear...not to accept graciously the burden of memory but to throw it back at the 
town's feet” (“The Counter-Monument” 277). It is through this lens that the texts in this study will be examined.

\section{Hawthorne \& State Memory: A Conflict}

Historians like Irving H. Bartlett regard the nineteenth century, but more specifically 1820 to 1860 , as one of the most important and crucial periods in the cultural history of the United States. It was a time of cultural, social, and political reform but also turmoil. Slavery had reached its peak, particularly in the American South. By 1860, there were close to four million slaves in the U.S. The beginning of the Women's Suffrage Movement was taking shape. Large-scale immigration from Germany, Ireland, and other parts of Western Europe began to occur. Transcendentalism, a philosophical movement, was forming and cultivated in the 1800s by such thinkers as Emerson, Thoreau, and Whitman. If a distinct American culture/identity can be said to exist, perhaps it was during this period that it began to take shape. If we recall some of the points made earlier regarding the formation of a community's identity, in which external forces political or social help define it, then it is clear why this moment in American history sets the scene for the main argument in this study.

Literature, as it often does, offered a much wider venue for expressing political and socio-economical ideas at a time when the United States was beginning to define itself into a nation of regional influence and power. Much like a child who begins to demonstrate a personality, forms an opinion and eventually develops an identity, America was a child, and Nathaniel Hawthorne, who lived through this crucial and important developmental period, was concerned as to what this identity would be, how the United States would shape and define itself, and what its future would be if this identity was 
malformed. Hawthorne was at times an outspoken critic of the social and political affairs of his time, as his published articles between 1862 and1864 in The Atlantic Monthly suggest. While in his fictional works there seems to be a sense of ambiguity and ambivalence not found in his critical work, they still pose a challenge to the validity of any single narrative of national identity that the social, cultural, and political agendas were trying to create.

Edward Said, in Culture and Imperialism, notes that “American attitudes toward American 'greatness,"” which includes its sense of its own "specialness" and "altruism," have "remained constant." So much that it "[has] obscured the realities of empire" (8). Hawthorne recognized the falseness of this "greatness" narrative, outlined by Said in Culture and Imperialism. Biographer Brenda Wineapple in her work Hawthorne: A Life asserts that Hawthorne was always concerned with "national hypocrisy" regardless of whether "he writes about Puritans, Tories, rebels, or transcendentalists" (350). His “Chiefly About War Matters,” published in The Atlantic Monthly in 1862, offended the magazine’s readers, according to Wineapple, "not because it frequently seems proSouthern but because it is so virulently and unequivocally antiwar - and this during a war fought for such a palpable moral good” (352). “Chiefly About War Matters” skewers the Northern narrative just as much as the Southern. This reluctance to side with official history or give in to a sole unified narrative is what I believe to be Hawthorne's signature mark. Hawthorne's texts work against the established state memory and the memory actively making itself all at the same time. This is the quality that makes his texts counter-monumental. 


\section{The Scarlet Letter and The Marble Faun: A Study}

In this study I will be looking specifically at Hawthorne's The Scarlet Letter (1850) and The Marble Faun: Or, The Romance of Monte Beni (1860). One of the main themes explored in The Scarlet Letter, as well as in many other Hawthorne texts like The House of the Seven Gables, for example, is that the sins of one generation are often visited on the next. The preface to The House of the Seven Gables conveys the major theme of the book, which Hawthorne refers to as a moral: "the wrongdoing of one generation lives into the successive ones, and . . . becomes a pure and uncontrollable mischief” (11-12). Similar sentiments are also expressed at the start of the "The CustomHouse” preface of The Scarlet Letter. The narrator, after divulging a disreputable family legacy, "prays that any curse incurred by them...may be now and henceforth removed" (10). While other texts like The House of the Seven Gables and several short stories like “The Artist and the Beautiful” might serve to expand on the arguments being made here, the narrower text selection for this study is not arbitrary.

Hawthorne did not set out to write counter-monumental texts. However, he was haunted by his family’s legacy, and counter monuments, are haunted by the remnants of the memory they are entrusted to preserve. In "The Custom-House” the authorial introduction to The Scarlet Letter, Hawthorne battles with the arguably cruel and harsh legacy his ancestors have left in their newfound land, Massachusetts. Hawthorne’s depiction of his Puritan ancestors, and those in The Scarlet Letter, could be attributed to a method of dealing with the family history he has inherited, along with the cultural identity he owes to Massachusetts. In this study that deals with American identity, The Scarlet Letter serves as the better choice for a national text. From the "The Custom- 
House," we can infer its nationalist commitments as it presents historical and ideological juxtaposition of Hawthorne's nineteenth-century frame of mind with the novel's seventeenth-century cultural and historical setting.

Chapter two, “Nathaniel Hawthorne’s The Scarlet Letter: The Counter Monumentality of Text in the Search for National Identity,” deals mostly with what I see as actual physical counter-monuments in the form of Hester, Pearl, and of course the scarlet letter A and their transformative powers, still tied in the same vein of national identity. Yet, perhaps one of the chief canonical mistakes in the history of pedagogy of American literature is the universal acclamation given to Hawthorne's The Scarlet Letter, which stages Hawthorne at his most non-cosmopolitan. If "cosmopolitan" is defined as multi-cultural, international, or global, then The Scarlet Letter is most certainly cosmopolitan. Not only do we have characters that are technically "international” (Hester herself was born in England), we also have Pearl, technically, an American citizen herself with cultural and inherited ties to Europe. In the text, we also know of cross-Atlantic voyages, adding to the novel's global spirit. In allowing ourselves to look at the text through this cosmopolitan and counter-monument lens, we can deduce Hawthorne's attitude about national identity, how it is defined, and the need for identity to be flexible.

In The Marble Faun, Hawthorne's last novel and the only novel not set in the United States, written on the eve of the American Civil War and widely popular in the years after its publication, he lays out questions and veiled answers as to his view of the causes of the Civil War and anxieties as to America's future. Yet, while The Scarlet Letter actually provides us with physical emblems of change as defined by Young, the revelation of The Marble Faun, as I argue in chapter one, "Circumstance, Choice \& 
Change: The Path of Preserving the Nation in Nathaniel Hawthorne’s The Marble Faun," is about the willingness to embrace change. A characteristic of the counter-monument I see attributed to the characters is their participation of the creation of national identity. Perhaps it comes as no surprise that it was published in Britain under the title Transformation. Written ten years after The Scarlet Letter and Hawthorne's long stay in Europe, The Marble Faun is a novel that raises questions about the concept of a nation or national identity. An identity is often defined in terms of common origin, ethnicity, or cultural ties, and whether an individual's membership in a nation should be regarded as non-voluntary or voluntary. When the novel is compared to the social/political issues governing the U.S. in the mid-nineteenth century, in particular the Civil War, and its European setting is analyzed, The Marble Faun offers readers a global narrative and perspective as to the issues of national identity. The Marble Faun also serves as a springboard for many of the arguments laid out in the subsequent chapter, which as previously stated argues that The Scarlet Letter is more cosmopolitan at closer inspection. Most importantly, examining The Marble Faun, alongside The Scarlet Letter, sheds light on the possible outcomes of individuals who are caught or tied in the wave of a changing national identity. Why are Hilda and Kenyon stateless? Why does Hester return to Boston? And why does Pearl choose to remain in Europe?

When looking at this study as a whole, it is important to note that any discussion on monuments/counter-monuments would be incomplete without a look at the people who designed and build them: the artists, both real and fictional. Young argues that fifty years ago when Lewis Mumford "pronounced the death of the monument," he ushered a new way of thinking for modern artists. Mumford believed that "the monument defied the 
very essence of modern urban civilization: the capacity for renewal and rejuvenation” (Young "The Texture of Memory" 4). Since then, the artists challenged with the task of remembrance have defined much of the counter-monument argument. It is they who are distinctly aware that traditional monuments do not serve an active purpose. With the artist in mind, it is important to note that this study relies heavily on art and looks closely at artists. They are the champions for counter-monuments, such as Jochen Gerzs and Esther Shalev-Gerzs, the artists who designed Monument against Fascism (1986). They had much involvement with the concept, design, and implementation of the monument. The artists decided on the monument's location, appearance, and subsequent disappearance. Monument against Fascism (1986) was lowered into the ground eight times during a span of seven years. At every lowering, Young points out, Jochen Gerzs and Esther ShalevGerzs attempted to ignite more and more of the local reactions, whether good and bad. It turned out that the Gerzes "found that even resentment is a form of memory" (qtd. in Young “The Counter-Monument” 281). With this understanding that artists play an integral role in the discussion of monuments and counter-monuments, it is important to note that almost all the characters in The Marble Faun are artists. The setting of Rome is riddled with monuments of a by-gone era. Throughout the text we come across weighty and lengthy discussions on the purpose of monuments, busts, sculpture and art in general. These discussions, along with the novel's setting, allow readers to discern elements of the counter-monumental as defined by Young and as propagated by artists. The same is found in The Scarlet Letter, as explored in chapter two. Hester is highly regarded for her artistic skill at the needle, and critics have often claimed the A stands for Artist. Not only are the artists important, but the art as well. One of the text's counter-monuments, the 
scarlet A, ignites local reactions similar to those caused by the Gerzes’ countermonument on the streets of Hamburg-Harburg, Germany. By exploring the artists’ view of counter-monuments, we are able to discern why, at the conclusion of The Scarlet Letter, the image readers are left with is a disappearing tombstone. Thus, when looking at this thesis as a whole, any discussion on monuments and counter-monuments would be incomplete without a proper look at artists themselves. 


\section{CHAPTER I: CIRCUMSTANCE, CHOICE \& CHANGE: THE PATH TO}

\section{PRESERVING THE NATION IN NATHANIEL HAWTHORNE'S THE MARBLE}

\section{FAUN}

Even though Hawthorne is hailed as an American literary icon around the world, in part thanks to his perceptive and discerning narratives about American life, he spent a great deal of time dealing in international relations and lived abroad in what some considered his most important political appointment. In 1853, President Pierce appointed Hawthorne to a four-year term as United States consul in Liverpool, England. It was described by Hawthorne's wife as "second in dignity to the Embassy in London” (qtd. in Mellow 415). The position was given to Hawthorne for the masterful job he did in writing Pierce's campaign biography, titled The Life of Franklin Pierce. At the close of the Pierce administration in 1857, his appointment ended, and the Hawthorne family toured France and Italy and again England before returning to the United States in 1860. The Hawthorne family’s sixteen-month residence in Italy saw much political action and change.

For many centuries, the Italian peninsula was a politically fragmented assembly of states, as was the case when the United States announced its independence from Great Britain in 1776. Although the Italian peninsula remained fragmented through the mid1800s, the concept of a united Italy began to take root. What was being promoted was a brand of Italian nationalism and the idea of a unified Italian political state. Political leader Guiseppe Mazzini declared a republic there. The revolutions of 1848 ignited nationalist sentiment throughout the Italian peninsula. The idea of the "Risorgimento", or national resurgence, continued to gain supporters. Due to the political turmoil, the Pope fled. 
French troops had to intervene to restore the Pope. The French remained in Rome for the next ten years to protect the papacy from nationalists (Kemp 209). The final push for Italian unification came in May 1859, the same month the Hawthornes left Italy. This tense and action packed political climate did not escape the notice of long term tourists, like the Hawthornes, but also like those we find in his last complete novel, The Marble Faun: or, The Romance of Monte Beni. It was his first book in seven years and published in 1860 upon his return to Massachusetts. Hawthorne rarely directly refers to the political turmoil; instead, he internalizes anxiety about nationalism by way of the psychological melodrama of the novel’s characters, three young American artists, Hilda, Miriam, and Kenyon, and one younger Italian, Count Donatello, who are all living in Rome.

The novel combines an elaborate, murder-mystery plot with a romantic setting, while Hawthorne's extensive descriptions of catacombs, museums, cathedrals, squares, towers, vineyards, and picturesque landscapes give the novel a travel guide feel. The Marble Faun is much concerned with art and sculpture as well. In fact, in the preface of the novel, Hawthorne states that Italy was chiefly valuable to him in writing the novel because it afforded him "a sort of poetic and fairy precinct, where actualities would not be so terribly insisted upon as they are, and must needs to be, in America” (iv). He laments that in his “dear native land,” it was so difficult for American writers to write “about a country where there was no shadow, no antiquity, no mystery, no picturesque and gloomy wrong” (iv). In fact, in Italy, Hawthorne finds himself in a place riddled with monuments, and in them, he finds a purpose. Unlike the United States, which at the time lacked sites of commemoration, Italy had them in abundance. However, it is what they come to represent for Hawthorne during his stay there, and for the American artists in the 
novel, that we come to learn his ambivalent attitude toward the meaning of monuments altogether and the role they play in creating an American “identity”. In fact, Hawthorne tells his readers in the very first chapter why Italy is the perfect setting for launching this argument:

We glance hastily at these things, at this bright sky, and those blue distant mountains, and at the ruins, Etruscan, Roman, Christian, venerable with a threefold antiquity, and at the company of world famous statues in the saloon, in the hope of putting the reader into that state of feeling which is experienced oftenest in Rome. It is a vague sense of ponderous remembrances; a perception of such weight and density in a bygone life, of which this spot was the center, that the present moment is pressed down or crowded out, and our individual affairs and interests are but half as real here as elsewhere. Viewed through this medium, our narrative [my emphasis], into which are woven some airy and unsubstantial threads, intermixed with others, twisted out the commonest stuff of human existence, may seem not widely different from the texture of our lives. (2) It is essential to note the narrator will repeatedly use the plural pronouns "us" and "we" throughout the text. When the narrator states, “our narrative,” he is speaking directly to the reading public, likely American, and invites them to look at this text as a case study that is "not widely different from the texture of our lives." In this statement, he is telling his readers that the novel is a parallel text to their specific moment in time. It is within this transformational historical and social context that The Marble Faun is created. 
Italy lends itself as an uninhibited space where Hawthorne, in The Marble Faun, imparts an understated message of the ways in which monuments of modern empire, like the United States, unlike those of ancient ones, must be by necessity tentative and uncertain in their power, relative worth, and importance to those who venerate them. This, in part, comes from social/political disputes happening back in the United States over differences of what exactly is commemoration, as well as concerns over development of the nation's capital. After all, a nation's monuments not only help shape and construct its identity, but also with time, define it. The Marble Faun, most importantly, raises the question as to how to establish a unique American culture different from its European ties, while at the same time allowing the incorporation of new cultures and an array of different "identities". Hawthorne does not ignore the issues the United States was facing pre-Civil War; in fact, he takes them on in a way only he can, in a case study of four friends who come to represent issues of identity posed by the Antebellum period. Miriam and Donatello come to represent the “other” the United States feared while Kenyon and Hilda are the white protestant ideal the United States embraces. However, the text complicates this simple parallel. It does not argue that the fluid, multifaceted, and emerging multicultural and racial American identity should be fixed and rendered impenetrable to outside sources. Instead, The Marble Faun suggests that if such a fixed identity were in fact achieved, then it would unavoidably and inevitably disintegrate and collapse under the weight of those outside forces the United States fought to exclude. To choose such a fixed identity, white, protestant and patriarchal, as Hilda and Kenyon do, is to choose a short-lived preservation at the cost of future deterioration, perhaps with disastrous repercussions. Hawthorne warns us that this fixed 
identity will crumble from marble into dust. It is with an understanding of Young's definition of monuments and Hawthorne's view that the identity of a nation should be fluid that makes The Marble Faun a counter-monumental text.

In History of the United States Capitol: A Chronicle of Design, Construction, and Politics, William Allen details the struggles the nation's capital went through to come to fruition. The present Washington, D.C/Northern Virginia area is comparable to Rome in relation to its numerous and grand monuments, as well as serving as the seat of government. During Hawthorne's time, the district went into economic decline partly due to neglect by Congress. According to Allen, the area constituted a major market in the American slave trade, and pro-slavery residents feared that abolitionists in Congress would end slavery in the District, thus causing a further depression in the economy. The citizens of Alexandria who profited greatly from the slave industry decided to petition Virginia to take back the land it had donated for the purpose of creating the national capital in 1791. This was done through a process known as retrocession. The original area ceded by Virginia, about 31 square miles, was returned to that state in 1847 . The United States finally had a piece of land to build the nation's capital. But what would it look like? What would be built? Historians like John Higham and William Allen have noted that in the 1850s there was an increased interest and effort in monument building in the nation's capital. However, there were issues as to what kind and even if the United States needed monuments. According to Higham, the impulse for monument building was a response to a national feeling of "the disturbing sense of remoteness from the heroic age of Revolution” (qtd. in Byer 164). What Americans hoped was that monuments would "rebuild a continuity with the past," in particular because they believed the country had 
lost that original republican civic boldness and virtue (Byer 164). As one American put it in 1846, monuments would "bring before us in our daily walks the idea of country in a visible shape.” He continues to say that we need “something tangible to cling to” (qtd. in Byer 164).

However, only two decades before, in 1800, Nathaniel Macon, a North Carolina Congressman, stood on the House Floor and declared, "since the invention of types [printing], monuments are good for nothing” (qtd. in Savage 1). Macon was referring to the proposal of a monument for the United States’ first president, George Washington. For Macon, words and not a pile of stones preserve the memory of great men and women. He believed that a modern, literate, and democratic nation had no need for such “pernicious acts of ostentation” (qtd. in Savage 1). Thirty years later, John Quincy Adams echoed the same antagonistic attitude towards monuments when he pondered why Congress still had not managed to build a national memorial to Washington. John Quincy Adams famously declared, "Democracy has no monuments. It strikes no medals; it bears the head of no man upon its coin; its very essence is iconoclastic” (qtd. in Savage 1). In the United States, the iconoclastic sentiment had strong cultural roots that stem back to ancient Greece, but the source of the sentiment was a revolutionary memory and critique of the monarchy, a system the U.S. fought to free themselves from. Philosophically, U.S. leaders of the time did not believe in reverence to a king or queen or their image. They believed that in their new democratic nation, no such reverence to any man or woman would ever be extended. Thus Macon, Adams, other political leaders, and many Americans were suspicious of monuments. They believed that true memory did not lay engraved in stone, but in the minds and hearts of the people, as well as in the literary 
tradition nourished by literacy and education.

These are the same sentiments expressed in The Marble Faun. The Eternal City, Rome, while ancient and historic compared to the relatively new United States, is eternal because it allows itself to be built anew with the passage of time. It is not eternal because it has remained stationary and intransigent:

The city of all time, and of all world! The spot for which man's great life and deeds have done so much, and for which decay has done whatever glory and dominion would not do! At this moment, the evening sunshine is flinging its golden mantel over it, making all we thought magnificent; the bells of all the churches suddenly ring out, as if it were a peal of triumph because Rome is still imperial. (67)

Using the imagery of decay in this quote, if we were to consider the present Rome, it is one that is built atop thirty feet of soil of the Rome of ancient days. Everywhere one looks in the text, there is not a single building, church, or monument that does not hold a trace of some ruin of an ancient structure, "almost everything that they beheld was medieval, though built, indeed, of massive old stones and indestructible bricks of imperial Rome; from the ruins of the Coliseum, the Golden House, and innumerable temples of Roman Gods, and mansions of Caesars and Senators, had supplied the material for all those gigantic hovels” (66). In fact, while walking through a suburban villa, the narrator comes across an artificial garden, riddled with false ruins, and the narrator exclaims, "What a strange idea, what a needless labor, to construct artificial ruins in Rome, the native soil of ruin!” (43). The narrator is struck dumb that in Rome there is a need to build artificial ruins when the current city is built atop and from these ruins. 
By emphasizing the notion of loss, the ruin, for the Romantics, took on a tragic meaning in pointing to the inescapable absence of continuity and/or unity. As such, the image or idea of the ruin became the basis of melancholic contemplation. However, if we look more closely at a ruin, we would see that it is also inescapably tied to modernity, to the notion of change, and to the belief that the present state of affairs is not the only one possible. Societies, by way of culture and the desire to archive, insist that monuments and ruins take on a fixed meaning in their endeavor to constitute a collective identity as well as a fixed sense of meaning. Yet, the ambivalence on the part of the ruin only allows meanings and memories to be temporarily ascribed to it. As a result, ruins cannot signify any immobile image of the past. Instead, what they do is symbolize the fluctuating and unpredictable relation between the present and the past. The ruins' flexibility is what has allowed the city to remain constant but ever evolving. From when the first Latins began to settle in Rome around 1000 B.C., to the great fire of Nero's time in 64 A.D., to the great gamble of Christianity, to the nineteenth century Risorgimento Hawthorne witnessed, there is a visible optimistic confidence in the text that Rome, no matter what, is capable and most importantly willing to accept change.

Rome's willingness to accept change is a sharp contrast to the hesitant and reluctant United States. Dale T. Knobel, in Paddy and the Republic: Ethnicity and Nationality in Antebellum America, argues that "the antebellum era...was one in which the Anglo American ethnic majority was preoccupied with self-perception and selfdefinition, with defining American nationality” (4). The issue lay not only in the struggle of how to define what it is to be American, but also how to differentiate the American self against the European, especially the nation the U.S. fought to free themselves from, 
England, but also from other European countries, in particular, Ireland. According to Julie Byrne of the National Humanities Center, "In 1850 Catholics made up only five percent of the total U.S. population. By 1906, they made up seventeen percent of the total population (14 million out of 82 million people)—and constituted the single largest religious denomination in the country.” These immigrants might have been "white”, but they were also Catholic. The growth of this religious denomination in a largely Protestant nation was problematic to the established national identity. However, religion was not the U.S.'s only concern. On the eve of the Civil War, part of this identity crisis also resulted from the African American population. Whether Catholic, free or enslaved, American identity was complicated by the fact that it was constituted differently from other national identities. Knobel explains that:

In contrast to the "historical" national people of the Old World, what made the Americans a nation at all was the republican polity, its laws, and shared rights and benefits citizens derived from it. Citizenship, not membership in what might be denominated a "Volk," was the basis for inclusion in the nation...(39)

Knobel's definition of national identity suggests that becoming a citizen of the United States was also to become an "American”. What this meant during Hawthorne's time was that simply the act of becoming a citizen contributed to the formation of an American identity. As such, given the influx of immigrants and the possibility of citizenship to millions of slaves through emancipation, this rendered the established white, Protestant, American identity vulnerable, while at the same time, and perhaps for the first time, challenged the strength, integrity, and validity of the founding fathers' model for the 


\section{United States.}

In the novel, Hawthorne associates these attitudes regarding the nature of national identity and the issues of commemoration in a conversation between two opposing characters. In a meeting in Kenyon’s studio between Miriam, our European “other”, and Kenyon, a young American sculptor who embodies the American ideal, we slowly learn Hawthorne's views of sculpture as an art and profession and whether immortalizing ourselves in marble is a futile effort. The conversation is so integral to the argument of the chapter that it should be quoted in full. However, it is also important to note that while a reader might assume it is Miriam speaking, the paragraph is not in quotes, and the narrator repeatedly uses the plural pronouns “us” and “we”. As such, this is another instance in which the novel makes an attempt to draw the reader into a shared discussion and examination of the issues facing America and its inhabitants at the time:

But it is an awful thing, indeed, this endless endurance, this almost indestructibility, of a marble bust! Whether in our own case, or that of other men, it bids us sadly measure the little, little time during which our lineaments are likely to be of interest to any human being. It is especially singular Americans should care about perpetuating themselves in this mode. The brief duration of our families, as a hereditary household, renders it next to a certainty that the great-grandchildren will not know their father's grandfather, and that half a century hence at furthest, the hammer of the auctioneer will thump its knock-down blow against his blockhead, sold at so much for the pound of stone! And it ought to make us shiver, the idea of leaving our features to be a dusty-white ghost among 
strangers of another generation, who will take our nose between their thumb and fingers and infallibly break it off if they can do so without detection! (72)

In reply to this statement, Kenyon quite breathlessly exclaims, "What you say goes against my whole art” (72). However, our narrator is not quite done here. Just before Kenyon shows Miriam a new bust he is working on, she chastises him because she believes he is working on a nude model. She states, "I am weary, even more than I am ashamed, of seeing such things” (72). In this case, we can be certain that it is Miriam speaking because her words are in quotes when she states, "but the difficulty goes to confirm me in my belief that, except for portrait busts, sculpture has no longer a right to claim any place among living arts. It has wrought itself out, and come fairly to its end.” To this, Kenyon replies, "Pray stop, Miriam, or I shall fling away the chisel forever!” (75). Miriam's argument that sculpture is a hollow form of art almost makes Kenyon give up his beloved profession as a sculptor.

But what is the alternative? To Miriam, her art, painting, is much more inclusive. "In painting,” Miriam states, "there is no similar objection to the presentation of brief snatches of time” (8). But better yet, the text offers us a living art that to the narrator supersedes everything else. Upon the group's examination of the statue of the Faun of Praxiteles, the narrator tells us that only a sculptor as well as a poet "could have dreamed of a faun in this guise, and then have succeeded in imprisoning the sportive and frisky thing in marble” (4). Miriam’s view of what is art, is not limited to poets, poetry and painting, but the sentiment expressed by the narrator is similar to what John Quincy Adams expressed on the House floor: identity, as well as a nation's collective memory, 
should not lie in stone but in a literary tradition nourished by literacy and education. A literary tradition is the differentiating factor between the "old world" and the new. If the United States wants to be part of the new, then it needs to look at what it wants to be known as, how that is achieved, and who gets to be a part of this new world.

The above paragraph's last concern, who gets to be a part of this new world, is also what The Marble Faun attempts to deal with. The novel's argument of national identity is twofold. Not only does it deal with the idea of monuments, but it also deals with immigration, religion, and slavery. The novel is centered around four friends, Hilda, Kenyon, Miriam, and Donatello. They each come to represent a facet of the American struggle with identity. Hilda and Donatello are the most thought-provoking of all the characters. They represent the connection where the United States' tensions over the construction of national identity during the pre-Civil War period and the idea of monuments merge. Hilda represents the susceptible white, Puritan, American identity influenced by religious and social influences of other ethnic, religious and racial identities. Donatello embodies the "otherness” the Faun of Praxiteles depicts. Their actions and responses to these potential influences indicate how threats against the national identity will fare within the new nation.

Of all the characters in the novel, Kenyon and Hilda are represented as white American. However, it is Hilda who is most tempted by outside forces. She is continually rendered as "a daughter of the Puritans" (31). She embodies purity and innocence, and is described as "the fair-haired Saxon girl...her customary white robes bore such an analogy to their snowy plumage [in reference to the doves she looks after] that the confraternity of artists called Hilda the Dove, and recognized her aerial apartment as the Dovecote” (32). 
Her susceptibility to outside influences is apparent early on in the text. Hilda arrives in Italy as an original American artist, but she is transformed into a copyist of the old European masters:

All the youthful hopes and ambitions, the fanciful ideas which she had brought from, of great pictures to be conceived in her feminine mind, were flung aside.... so Hilda became a copyist...she chose the better and loftier and more unselfish part, laying her individual hopes, her fame, her prospects of enduring remembrance, at the feet of those departed ones whom she so loved and venerated. (33-35).

Had she remained in the United States, she might have produced original art worthy of being hung in a gallery; however, the text seems to remain undecided about her artistic transformation, wondering whether perhaps "the result of her Italian studies, so far as it could yet be seen, will be accepted as a good or desirable one” (32). The narrator ends this chapter by asking "Would it have been worth Hilda's while to relinquish this office for the sake of giving the world a picture or two to which it would call original; pretty fancies of snow and moonlight; the counterpart in picture of so many feminine achievements in literature!” (36). Hawthorne’s sexist view of women’s writing is well known, so it comes as no surprise that a similar sexist sentiment is expressed here. If it is possible to look beyond the sexism, what we get is a rhetorical question implying that there is nothing wrong with Hilda's transformation from an original American artist to a copyist of European art. While it sounds unpatriotic that is not Hawthorne's intent. The suggestion here is that an original American artist should and is allowed to open him or herself up to outside sources, in this case, the old European masters of art. 
Apart from art, the most intimidating European threat for Hilda is Catholicism. Hilda is alone in Italy and has no spiritual guidance. She, therefore, often turns to Catholicism and in particular the Virgin for solace. While the text looks at theological differences between Catholicism and Protestantism, it is also a debate on to how to respond to the influx of Germans and other ethnic immigrants, and more specifically European Catholics, as well as African Americans, as characterized by Miriam and Donatello. Dale T. Knobel provides insight into this ongoing discussion in the United States:

Blacks, slaves and free, were not properly Americans, though native born, but "aliens-political-moral-social aliens," Henry Clay thundered in the Congress of the United States. "We are decidedly more exclusively ‘American' than many of our white brethren,” the editor of New York City’s Colored American roared in rebuttal. "Puritanism, Protestantism, and True Americanism are only different terms to designate the same set of principles,” said the Presbyterian evangelist Charles Boynton from his Cincinnati pulpit. Roman Catholic convert Orestes Brownson taunted back, "Protestantism is not and cannot be the religion to sustain democracy.” (5)

From the insight Knobel provides in his study, it is evident that this argument as to who was or wasn’t considered “American” was creating a strain across the U.S. From the three most important places these arguments were usually heard from—-the pulpit, the media, and at the seat of government—it is clear that opinions varied and that no clear answer was being reached. The Marble Faun adds to this discussion in a veiled moral 
examination of whether Miriam and Donatello will pay for the murder of the model and if Hilda, the only witness to the crime, will fall for the temptation of Catholicism's power of absolution in the guilt she carries for having witnessed the crime.

Donatello and Miriam are the characters least likely to be viewed as American. Donatello is not American. He is an aristocratic Italian, whom his friends impart subhuman qualities to in his likeness to the Faun of Praxiteles: "the Faun is a statue of a young man, leaning his right arm on the trunk of a tree, one hand hangs carelessly by his side...his only garment—a lion's skin, with the claws upon his back shoulder—falls halfway down his back, leaving the limbs and entire front of the figure nude” (3). In his wartime essay, "Chiefly about War-Matters" published in The Atlantic Monthly, Hawthorne comes across a band of fugitive slaves. Hawthorne's description of the slaves directly echoes his characterization of Donatello in the text. These fugitives incite Hawthorne to try to capture their uncanny meaning, "so rudely were they attired, as if their garb had grown upon them spontaneously, so picturesquely natural in manners, and wearing such a crust of primeval simplicity, they seem a kind of creature by themselves, not altogether human, but perhaps quite as good, and akin to the fauns and rustic deities of olden times [my emphasis].” Donatello and Miriam are, among other things, also a romanticized version of the African-American slave. The murder Donatello commits, along with the transformation of his character, can be read as an examination of the possibility of transforming a Faun, a sub-human character, into a human, or more specifically, a slave into a citizen.

Miriam is the other character in the text that represents this "otherness". The fact is no one knows anything about Miriam. Her origins are obscure. She simply shows up 
one day in Rome "without introduction" (10). There are "wild and romantic fables," about her origins. "It is said, for example, that Miriam was the daughter and heiress of a great Jewish banker... another story hinted that she was a German princess... according to another statement, she was the offspring of a Southern Planter...but the one drop of African blood in her veins so affected her with a sense of ignominy, that she relinquished all and fled her country” (11-12). In each of these embodiments, Miriam simply does not fit the model for inclusion in a homogenous group with analogous identity. If we read her as a Jewess, like Elissa Greenwald suggests in "Hawthorne and Judaism: Otherness and identity in The Marble Faun,” we find Hawthorne uses Judaism to develop ideas about history, alienation, religious tolerance, and woman as Other. If we read her as a tragic mulatta, as Eve Raimon suggests in The Tragic Mulatta Revisited: Race and Nationalism in Nineteenth-Century Antislavery Fiction, she is still a symbolic vehicle for explorations of race and nation, both of which were in crisis in the mid-nineteenth century. She fits the tragic mulatta stock character because the text proposes that she is fleeing this mysterious personage, the model, who by some unknown means has this power over her. During one encounter, the model tells her, "You must throw off your present mask and assume another," while reminding her of "the power I have over you” $(56,58)$. However, the narrator refuses to clarify what is the nature of that power while at the same time hinting at some sin and guilt of an unspecified crime. "Men have said that this white hand had once a crimson stain...it looks very white, but I have known hands as white, which all the water in the ocean would not have washed clean” (58).

The crime behind the crimson stain is never known; however, the painting of Beatrice Cenci by Guido Reni and the legend surrounding Beatrice figures prominently in 
the text. Beatrice Cenci was the victim of incest by her father. She, her siblings, and their stepmother bludgeoned him to death. The novel's two opposing female characters, Hilda and Miriam, debate the nature and extent of Beatrice's guilt. Hilda believes Beatrice's act to be an "inexpiable crime," but Miriam believes it was "no sin at all, but the best possible virtue in the circumstances” (39). This direct association ties Miriam to the figure of the tragic mulatta, who may be the victim or product of incest, or a partner in such a crime. If we look at Miriam as this figure, then the model too is associated with this tragedy; his true identity, even more so than Miriam’s, remains positively murky. Under Miriam’s encouraging gaze, Donatello throws the model off a cliff. Symbolically, throwing the model off the cliff is akin to a cleanse. It is a shedding and ridding off of the lingering identity of slavery and most importantly, otherness, personified as the model. The shedding of a fixed identity, in this case one of 'otherness' is a counter-monument trait.

We already know that Hilda has been influenced both by the art of the masters and has been flirting with Catholicism. However, her witnessing the murder of the model brings on her greatest trial, one of faith. Hilda is bound by what Barbara Welter calls “The Cult of True Womanhood 1820-1860”, in which a woman’s attributes were "judged by herself [and] by her husband, her neighbors and society [these attributes were divided] into four cardinal virtues—-piety, purity, submissiveness, and domesticity. Put them all together and they spelled mother, daughter, sister, wife—woman” (152). Compared to Miriam, the dark, ethnic "Other," corrupted by her complicitness in a crime, Hilda lives in an ivory tower whose lofty height has enabled her to remain above and untouched by sin and corruption until that fateful night. Hilda’s flirtation with 
Catholicism is evident even before she witnesses the murder. Apart from living in this ivory tower, a duty Hilda takes all upon herself, is keeping the light of the Virgin’s shrine from going out. Miriam tells her, "I should not wonder if the Catholics were to make a Saint of you, like your namesake of old; especially as you have almost avowed yourself to their religion, by undertaking to keep the map a-light before the Virgin's shrine.” To which Hilda replies, “No, no Miriam! You must not call me a Catholic. A Christian girl, even the daughter of the Puritans, may surely pay honor to the idea of divine woman hood, without giving up the faith of her forefathers” (31). Can Hilda, in fact, pay such tribute to the Virgin and remain Protestant? This instant is not the first time Hawthorne has embraced a conflict of faith. In The Scarlet Letter, the Virgin Mary makes an appearance. When Hester emerges from prison with her child and stands on the pillory, the narrator shifts his view to that of an imaginary Papist. While the following quote is a famous and quoted section, it has direct application to Hilda: "Had there been a papist among the crowd of Puritans, he might have seen in this beautiful woman, so picturesque in her attire and mien, and with the infant at her bosom, and object to remind him of the image of Divine Maternity...” (48). The narrator goes on to contemplate the contrast of "that sacred image of sinless motherhood" to "the taint of deepest despair" to which he attributes "that the world was only the darker for this woman's beauty" (48). Here Hawthorne reaches a distorted conclusion about the Puritan's belief of sin and sinfulness; however, for Hawthorne, he still considered it a dangerous element of their teachings. The Virgin for the Puritans was neither divine nor an eternal virgin, a direct contradiction to Catholic theology; but, in Hester, an unwed mother, and Hilda, the daughter of Puritans, she stands as a representation and figure of Womanhood worthy of veneration. 
After the murder of the model, Hilda's mutable dependence upon the Catholic faith deepens. She goes from tending the shrine and admiring the Virgin to actual praying, but not directly to God. Anglican doctrine teaches that there is no need for a “middleman” like a Catholic saint. While at St. Peter’s, a painting of Guido’s Archangel treading over a prostrate fiend overwhelms her. The moral of the painting, she believed, "appealed as much to Puritans as Catholics.” Thus the narrator tells us as if in a trance or dream:

Hilda found herself kneeling before the shrine, under the ever-burning lamp that throws its rays upon the Archangel's face. She laid her forehead on the marble steps before the alter, and sobbed out a prayer; she hardly knew to whom, whether Michael, the Virgin, or the Father; she hardly knew for what, save only a vague longing that thus the burden of her spirit might be lightened a little. (219)

Hilda herself lays prostrate on the floor of Saint Peter's like the fiend in the painting, an act implying that she should also be made to suffer. As Emily Schiller argues in "The Choice of Innocence: Hilda in The Marble Faun,” Puritans believed that "all men, women, and children, without exception, are fallen, and only a few are destined for salvation” (380). In fact, while treading the streets of Rome from picture gallery to picture gallery wallowing in her guilt, she comes across a young man in silent prayer by a statue of a saint. The narrator tells us, "If the young man had been a protestant, he would have kept all that torture pent up in his heart, and let it burn there till it seared him into indifference” (215). After all, Hilda as a self-described Puritan should identify with sin rather than with salvation, for to be a Puritan one must believe in one's innate depravity, 
and she would not have done what she did next. Hilda, driven by her guilty conscience and grief after spending the summer months in solitude has the most direct confrontation with Catholicism in the novel.

In the chapter aptly titled "The World's Cathedral," she observes men and women from all nationalities at the confessional. She watches a woman exit and cannot help but speak to her: "You look very happy! Is it so sweet, then, to go the confessional?” The woman replies, “Oh, very sweet, my dear signorina! My heart is at rest now. Thanks be to the Saviour, and the Blessed Virgin and the Saints, and this good father, there is no more trouble for poor Teresa!" (221). So Hilda finds the confessional inscribed "PRO ANGLICA LINGUA" and lays open her heart and terrible secret to a priest. While she understands that she has not had absolution, for according to her, "Only our Heavenly Father can forgive my sins," her experience in the confessional is not one associated with evil or superstition (223). In fact, after the confession, she feels "like a new creature," and she blesses the hour that brought her to "this beautiful and glorious cathedral" (226).

Hilda resists a final confrontation when the priest offers to convert "a heretic," as she re-asserts her identity as a Puritan; however, she does allow and accept his blessing. This moment signifies a possible compromise between a Catholic and Protestant U.S., and thus a unified identity, which supports Christian goodwill, brotherhood, and the belief in God. Kenyon is astonished that Hilda would seek solace in the Catholic Church and shouts at Hilda, "Have you flung your angelic purity into that mass of unspeakable corruption, the Roman Church?” (227). Yet, Kenyon, the figure most closely associated with white, Protestant America, is not without temptation. While spending the summer with Donatello in his villa, he accompanies Donatello on a penitent's journey. The church 
might be depicted at times as seductive and as having tested even the strongest Puritan stronghold, Kenyon, but what this moment teaches us is that the Catholic Church is a manageable threat in the U.S. and does not warrant complete exclusion from American society.

But if religious diversity, specifically Catholicism, is to be tolerated, what becomes of our African Other? In how the novel deals with Miriam and Donatello, we find our answer as to how American society will respond to this threat. The fate of Miriam and Donatello is quite clear. Hilda and Kenyon's rejection of Miriam at the novel's conclusion and Donatello’s imprisonment for his crime sheds light as to whether the U.S. is willing to accept all members put forth as candidates for the formation of national identity. During the group’s observation of the Faun of Praxiteles, the narrator foreshadows early on that Donatello’s place in society will never fully be realized:

The being here represented is endowed with no principle virtue, and would be incapable of comprehending such; but he would be true and honest by dint of his simplicity.... it is possible too that the Faun might be educated through the mediums of his emotions, so that the coaser animal portion of his nature might eventually be thrown into the background, though never utterly expelled. (4)

The threat of social contamination on all levels, from the genetic to the political, that would be proposed from the inclusion of African American as citizens is simply not allowable. In the case of Miriam, while she avoids any prison time for her involvement, she is stained by her presumed African heritage as well as by her inferior moral compass. Hilda outright states that the U.S. cannot risk further contact with the "Other": 
...I am a poor, lonely girl, whom God has set here in an evil world, and given her only a white robe, and bid her wear it back to Him, as white as when she put it on. Your powerful magnetism would be too much for me. The pure, white atmosphere, in which I try to discern what things are good and true, would be discoloured. (128)

From Hilda's statement as she vows never to see Miriam again, we can discern that it is more than an earthly duty to keep a national identity homogenous. More alarmingly, while the Catholic Church is at least given a chance, Miriam and Donatello almost certainly lost the race before it even began. If we look back at Knobel's definition of national identity that suggests that to become a citizen of the United States was also to become an “American,” then The Marble Faun appears to suggest that figures like Miriam and Donatello, among “Other” ethnic minorities, simply cannot be granted citizenship if that means that the pure, white, protestant, patriarchal national identity will be compromised. As such, the title of "American" can only be justly given to Kenyon and Hilda, when at the novel's conclusion they are married, and presumably return to America to produce future "Americans," thus securing this national identity.

Reading The Marble Faun as a call to choose or prefer a homogenous society is certainly a pessimistic one. If we take it at face value, we would be saying that Hawthorne, a canonical novelist, recognized as such in his own time, was advocating sentiments akin to those white supremacist groups, knowing the U.S. reading public valued his opinion. We also must look at the time when the novel was published: almost one year before the start of the Civil War, an event Hawthorne knew was inevitable. But if we take an even further look at the discussion of the painting of Beatrice Cenci 
between Miriam and Hilda, as Diane Hoeveler suggests in "Beatrice Cenci: Hawthorne, Melville and Her Atlantic-Rim Contexts," we will find that Hawthorne's message in The Marble Faun is not entirely pessimistic. Hoeveler points out that Hawthorne is peculiarly sympathetic to the sins of Beatrice, incest and parricide, as mentioned before. In his Italian and French Notebooks, there are entries referring specifically to the painting of Beatrice Cenci. The entry for the $20^{\text {th }}$ February 1858 reads, "Cenci is the most profoundly wrought picture in the world." On the $15^{\text {th }}$ of May 1859 , he continues: "the picture is quite indescribable, inconceivable, and unaccountable in its effect” (qtd. in Hoeveler par. 21). According to Hoeveler, this strange admiration "can only be explained by interpreting Beatrice as a figure who represents an admirable and necessary human quality: the desire to destroy evil and replace it with a new order” (Hoeveler par. 25). Beatrice does this by committing murder. She kills her father. While the model might seem like a group delusion at one point when he appears in the Catacombs, his haunting of Miriam is an aspect of her African heritage, and the speculation surrounding his identity and conjecture that he may be "a political offender, or an assassin” juxtaposes with his symbolic death, flung of the Traitors Leap, an ancient execution cite for traitors and political enemies. If we tie this all together with Hawthorne's interpretation of Beatrice, we can conclude that the evil of slavery can be erased if we choose to erase it and build a new inclusive nation.

Hawthorne warns us that if our choice is one of hypocrisy and betrayal, like that of Hilda’s and Kenyon’s, as is outlined in Blythe Ann Tellefsen’s essay “'The Case with my Dear Native Land': Nathanial Hawthorne's Vision of America in The Marble Faun,” the nation fares a bleak future. Tellefsen wisely points out, “Hilda’s rejection of Miriam 
rests not on moral duty but in personal, selfish desire to preserve her own peace of mind and perceived 'spotlessness' at the expense of her friend” (477). However, the narrator reveals that the future Hilda and Kenyon envision back in the U.S. might not be as secure as they hope:

Now that life had so much human promise in it, they resolve to go back to their own land; because the years, after all, have a kind of emptiness, when we spend too many of them on a foreign shore...but, by and by, there are no future moments; or if we do return, we find that the native air has lost its invigorating quality, and that life has shifted its reality to the spot where we have deemed ourselves only temporary residents. (287) Their native air is no longer their own. The "reality of life" is the one Rome offers as a heterogeneous space where diverse people like Hilda, Donatello, Kenyon, and Miriam can come together, and things like art, sculpture, poetry and religious acceptance can find balance. In their unrelenting selfishness and desire to maintain a pure national identity, they have come to realize that they are the ones who do not fit in anywhere: "thus, between two countries, we have none at all” (287). The price Hilda and Kenyon pay for their choice is to be destined forever to roam an empty space where they find nothing, not even "a little space of either in which we can finally lay down our discontented bones" (287).

If we refer to one of the last chapters in the novel, we might remember that Kenyon encounters a half buried statue (which Miriam and Donatello discover) on an ancient dig. Tellefsen argues that this instant evokes a salient question posed by the novel. Kenyon looks at the statue and exclaims, "I seek for Hilda, and find a marble 
woman! Is the omen good or ill?” (163). Hilda is a marble woman, cold, distant, severe, but if we recall Miriam's argument of the art of sculpture and America’s insistent desire to be remembered in that form, we discover the mockery in their attempt to preserve national identity in the figure of Hilda. In fact, she is a broken and forgotten statue that “seemed to fall asunder again, and become a heap of worthless fragments” (264). Hawthorne does not directly or explicitly confronts issues of national identity, or history for that matter, rather he does so through the psychological melodrama and murky stories of Miriam and Hilda. The text joins these veiled concerns to characteristically singular symbolic images, like the marble woman Kenyon finds, that concretize his anxiety, making his art one of counter-monumentalism. The careful reader or interpreter participates in counter-memory, the same in the Custom-House preface as the next chapter will show, by giving due weight to these symbolic/concretized images or scenes, even though they may seem like casual references to art. We can conclude by stating that The Marble Faun is a novel about choice, and choice means flexibility and possibility. The choice is to allow an American identity to take shape as it will and not cast it in stone, thus accepting the counter-monumentality that is change. 
CHAPTER II: NATHANIEL HAWTHORNE’S THE SCARLET LETTER: THE COUNTER MONUMENTALITY OF TEXT IN THE SEARCH FOR NATIONAL IDENTITY

The Scarlet Letter actually provides us with the physical emblem of change as defined by Young. A close reading of the novel reveals that the scarlet letter A Hester is condemned to wear on her chest for the rest of her life, Hester herself, and most captivatingly Pearl serve as the intermediaries for change. In addition, when we stop to look at Hawthorne's work more closely and realize that this seventeenth century setting is actually a platform he uses to speak about nineteenth century problems, then our window for interpretation and analysis opens, and hopefully our desire for answers is satisfied. The Scarlet Letter, much like The Marble Faun is the medium for issues of race and Catholicism, also serves as the medium in which Hawthorne addresses the national values of his time, and in this case his concern over the overwhelmingly powerful religious and philosophical groups like the Transcendentalists.

If we add the counter-monument layer to our analysis, then we can also interpret what Hawthorne intends us to do with the information. To some extent, the answer to whether Hawthorne cared about American identity or whether he was political might be no. However, while pinning down exactly what that identity should be according to Hawthorne is much more allusive, it is evident that he was concerned as to what this identity would be, how the United States would shape and define herself, what her future would be if this identity was malformed, or if she should fall because of a unyielding stance on change. What is clear to me is that even though the U.S. is flawed, and Hawthorne has no problem admitting this, there is an innate desire to guide and protect 
her from ruin should the nation ever become a hostile, intolerable, inoperative, statue like nation or community.

“The Custom-House,” the authorial introduction to the novel, is important as it juxtaposes Hawthorne's nineteenth-century frame of mind with the novel's seventeenthcentury cultural and historical setting. The sketch also provides a frame for the main narrative of The Scarlet Letter. It is in the Custom-House that the narrator finds the tattered A. The nameless narrator, who we can presume to be Hawthorne because of the autobiographical aspect of “The Custom-House," takes a post as the "chief executive officer of the Custom-House,” where taxes are paid on foreign imports into a country (12). The very first description from the narrator is that Salem, as a port city, while "a bustling wharf" half a century before, is now "burdened with decayed wooden warehouses, and exhibits few or no symptoms of commercial life; except, perhaps, a bark or brig, half-way down its melancholy lane" (6). No one seems to care about "the border of unthrifty grass” that grows between the cobblestones, but again it is a sign that the grass has grown so much so as "to show that it has not, of late days, been worn by any multitudinous resort of business” $(6,7)$. The harbor basically lies in ruin, and more importantly, economically, it fails to generate any income for the town and state. What is worrying about this description is that it was once a port with a promising future, but alarmingly, it has failed to continue in the process of maturation into a major harbor given its important location for trade and transport. The only building left intact in this decaying town is the Custom-House, a government building, wholly due to the fact that it is made of brick. Above the entrance what hovers, according to our narrator, is an "enormous specimen of the American eagle" (6). Here is the first sign that the narrator is 
at odds with this quintessential American patriotic symbol, and it foreshadows not only his bitterness at having been dismissed from his post as surveyor of the Custom-House but the ambivalent nature of symbols in general.

There is no doubt the eagle looks fierce with its "shield before her breast...[and] a bunch of intermingled thunderbolts and barbed arrows in each claw...[B]y the fierceness of her beak and eye and the general truculency of her attitude, [she appears] to threaten mischief to the inoffensive community" (7). But, according to the narrator, "vixenly as she looks many people are seeking to, at this very moment, to shelter themselves under the wing of the federal eagle; imagining, I presume, that her bosom has all the softness and snugness of an eider-down pillow” (7). He is very quick to inform his reader how swift change can happen to those who might mistakenly seek shelter in the wings of the eagle: "but she has no great tenderness, even in her best moods, and, sooner or later, -oftener soon than late, -- is apt to fling off her nestlings with a scratch of her claw, a dab of her beak, or a rankling wound from her barbed arrows” (7). There is no security in the seemingly safe sanctuary that is the nest of the eagle, the state. Ready or not, the eagle will fling its hatchlings, its citizens, into the unknown without any regard for their readiness or likelihood of survival.

Just like safety in the wings of the eagle is tentative, his fellow co-workers do not hold much promise either. Like the wharf, they are feeble and frail old men, who mostly hold lifetime appointments: "two or three of their number...being gouty and rheumatic, or perhaps bedridden, never dreamed of making their appearance at the Custom-House, during a large part of the year” (13). The narrator finds them to be generally and greatly incompetent and mildly corrupt. The narrator has consolation that "through [his] 
interference, a sufficient space was allowed them for repentance of evil and corrupt practices, into which, as a matter of course, every Custom-House officer must be suppose to fall,” and thus not even a government employee is blemish free. Our narrator admits that he cannot bring himself to fire any of them, even though "they knew...that by their own lack of efficiency for business, -- they aught to have given place to younger men, more orthodox in politics, and altogether fitter than themselves to serve [their] common Uncle” (14). From reading these first introductory pages of the sketch, it is clear that the narrator is nothing like these men he is now in charge of.

The narrator is from a different generation. His intellect and past experiences distinctly mark him as a man of the times; however, he "took it in good part at the hands of Providence, that [he] was thrown into a position so little akin to [his] past habits” (23). He thinks it is time at last he should exercise other faculties of his nature after his "fellowship of toil and impractical schemes, with the dreamy brethren of Brook Farm," more specifically, writing. (23). In this passage, the narrator details that for three years he basically has been living a Transcendentalist way of life. He has spent time with "Thoreau talking about Pine trees," and "wild free days on the Assabeth" but he now desires change; he craves it (23). So much so because he feels that this way of existing might do more harm than good to the individual: "it might be true, indeed, that this was a life which could not, with impunity, be lived too long; else, it might make me permanently other than I have been, without transforming me into any shape which it would not be worth my while to take," but he has the cautionary frame of mind to "never consider it as other than a transitory life" (23). So what better place is there to put an emblem of change, a counter-monument, than in a community Hawthorne knew too well, 
a community whose past actions still cause ripples of anxiety and perhaps shame in his mind? He does not fear that the Puritan community of his ancestors will be reborn in nineteenth-century America. What he fears is the rebirth of the rigidity that is symptomatic to Puritan beliefs, but in his own time in the formation of a philosophical system that fosters the same ideological rigidity in the form of individualism. This was a philosophy Hawthorne knew and experience during his time in Brook Farm, but also one he learned to doubt.

At their most fundamental level, transcendentalists believed that people are at their best when truly self-reliant and independent. Emerson wrote in "Self-Reliance," "To believe your own thought, to believe that was is true for you in your private heart, is true for all men; that is genius” (Par. 1). However, Hawthorne was aware that the individual could not transcend the community and apprehensive that a group of people could truly live that way for long without possible long-term consequences to the wellbeing of that community. In The Scarlet Letter, if one could "transcend,” meaning that the physical and empirical is only realized through the individual's intuition, rather than through the doctrines of established religion, then Hester's punishment would be meaningless because it does not hold any power over the members of the community, but in the novel, it does. In a non-fiction environment, if an individual is able to transcend, then that means that the members of that community do not need one another. Is this notion not idealist? At first glance, it is, but on closer inspection, is this way of life even possible, and even if it was, at what cost to the individual and society?

Although scholars like Alfred Rosa cite Hawthorne as a member and supporter of the Transcendentalist movement, he was, in fact, at odds with it. His relationship with 
Emerson and the transcendentalist community was to say the least, uncomfortable. He questioned the power transcendentalist leaders had over their supporters, a key sign to Hawthorne that this movement was questionable. Hawthorne, in the preface for Mosses from an Old Manse, devoted a section to Emerson. In it, he seems dismissive of Emerson and provides insight into Emerson's mesmerizing quality over others. Hawthorne wrote:

His mind acted upon other minds, of a certain constitution, with wonderful magnetism, and drew many men upon long pilgrimages, to speak with him face to face...Uncertain, troubled, earnest wanderers through the midnight of the moral world, beheld his intellectual fire, as a beacon burning on a hill-top, and, climbing the difficult ascent, looks forth into the surrounding obscurity, more hopefully than hitherto. The light revealed objects unseen before-mountains, gleaming lakes, glimpses of a creation among the chaos. (qtd. in Person 21)

To an unknowing reader, without any knowledge of whom the author was describing, some level of skepticism and/or suspicion might arise as to the natural power of leadership of someone who can make pilgrims out of people and cause them to travel long distances for "glimpses of a creation among the chaos." By the end of this passage, Leland Person asserts that Hawthorne, while not outright stating it, makes Emerson look like the leader of a cult. However, the issue at hand for Hawthorne was that transcendentalism itself seemed too dreamy and optimistic. He critiques such "deformed idealism and its potential harmful consequences in such tales as 'The Birth-mark' and 'Rappaccini’s Daughter”' (Person 21). 
Now we are left in a strange situation. Here is a man who desires change, but cannot bring himself to initiate any in the Custom-House. So how is change to come about without action? The narrator establishes his desire to take up writing again: "the thoughts, that had seemed so vital and so active, yet had been put to rest so quietly, revive again...the habit of bygone days awoke in me," so much so that he offers "the public the sketch which I am now writing” (25). Contrary to his Puritan ancestors’ assertions that writing is frivolous, he finds it therapeutic, but most importantly also practical, unlike his Transcendentalist friends who wanted to create an intellectual tradition. In the long run they were criticized because they lacked concrete ideas, choosing instead to dwell in a foggy abstract world of their own creation. And so, the sketch was inspired by having wondered "one idle and rainy day" onto the second floor of the Custom-House and finding "a small package carefully done up in a piece of ancient yellow parchment," belonging to “one Jonathan Pue, Surveyor of his Majesty’s Customs for the port of Salem, in the Providence of Massachusetts Bay” (26). Amongst the two-century old letters, notes and documents, what drew the attention of the narrator "was a certain affair of fine red cloth...[with] traces about it of gold embroidery.” To him "certainly, there was some deep meaning in it, almost worthy of interpretation, and which, as it were, streamed forth from the mystic symbol, subtly communicating itself to my sensibilities, but evading the analysis of my mind” (28). The mystic symbol might have evaded an analysis of the mind because what it really required was an analysis of the heart. The strange power of the scarlet letter could only be felt. When the narrator places the letter on his breast, he "experienced a sensation not altogether physical, yet almost so, as of burning heat; and as if the letter were not of red cloth, but red-hot iron” (28). It is there, at 
that moment, that he decides that from the old surveyor's original papers and the scarlet letter itself, he will craft a tale and imagine "the motives and modes of passion that influenced the characters who figure in it” (29). To the narrator, coming across this mysterious package might not have been an accident, but a long fated duty, imparted to him by the old New England surveyor who the narrator affirms had a "filial duty and reverence....as [his] official ancestor," and said, "I charge you, in this matter of old Mistress Prynne, give to your predecessor's memory the credit which will be rightfully its due!” The narrator said to the ghost of the surveyor, “I Will!” (30). Taking the pledge, the narrator is now bound not only by filial duty, but by the echo of Hester's own familiar call through time, the iron hot heat of the scarlet letter and the narrator's eerily similar circumstances to Hester. The narrator's connection with Hester enables the reader to universalize her story thus forming a connecting thread from the past into the present. In "The Custom-House," he calls his firing a decapitation, "my own head was the first that fell!” suggesting that he, like Hester, had been placed on a scaffold (36). He sees himself as an artist, also like Hester, the most un-political of people, who had been victimized by politicians and the law in the same vein as the debasing punishment Hester bears up on the pillory.

Even though he is still bitter from his dismissal, according to the narrator, it is the best thing that could have happened: "in view of my previous wearisomeness of office, and the vague thoughts of resignation, my fortune somewhat resembled that of a person who should entertain an idea of committing suicide, and, altogether beyond his hopes, meet with the good hap to be murdered” (36). So much for this figuratively decapitated, politically dead man, because all this time, according to our narrator "the real human 
being...with his head safely on his shoulders, had brought himself to the comfortable conclusion, that everything was for the best; and, making an investment in ink, paper, and steel pens, had opened his long-disused writing desk, and was again a literary man” (37). Hawthorne, like the narrator, still had to balance the need to establish a weighty past with the equally compelling need to write an interesting and relevant story. Neither Hawthorne nor the narrator wants to see his work branded as only American. Americanness remains both a promise and a threat, just as the eagle over the Custom- House door offers shelter while at the same time appears ready to attack. The tale of The Scarlet Letter may add to the legitimacy and legacy of American history, culture, and identity, but in order to do so it must surpass its Americanness and establish a universal appeal. Only then can American culture hold its own in the world as a nation.

While the novel was very well received, it seems that when the first edition of The Scarlet Letter was published, many readers were upset with "The Custom-House” sketch. In the preface to the second edition of The Scarlet Letter, dated March 1850, Hawthorne expresses what appears to be an apology for offending the public, stating that he did not expect his work to have such an incendiary effect on its readers. However, what the preface really shows is Hawthorne unmoved by the protests against the sketch. He wrote: The sketch might, perhaps, have been wholly omitted, without loss to the public or detriment to the book, but having undertaken to write it, he conceives that it could not have been done in a better or a kindlier spirit, nor, so far as his abilities availed, with a livelier effect of truth. The author is constrained, therefore, to republish his introductory sketch without the change of a word. (3) 
Hawthorne's objective in keeping the sketch in the second edition was not to attack the people who dawdled around in the Customs-House rather than do their civic duty, or even those who pushed to have him fired because of his political affiliation, and certainly not the faithful reader. Rather, Hawthorne chose to present an example, "not [to] the many who will fling aside his volume, or never take it up, but the few who will understand him better than most of his schoolmates or lifemates,” in an attempt to caution the members of his community of a serious problem that he believed was eroding the nation at its footings (5). To Hawthorne, those that objected to the sketch were unmindful of the point he was truly trying to convey. Those that understood saw a problem with the rotting and stagnant port. Alert readers would question not only why it was in such a state, but why would the government allow it. These readers were the most aware of the dangerous consequences of a fixed state. It is they whom Hawthorne is addressing. After "The Custom-House," a reader might expect to be taken chronologically through the safe, comforting, typical plot structure of fiction; however, this is not what Hawthorne has selected. For a change, he decides to thrust the reader into the center of the town's market place where Hester emerges from the prison, babe in arms, to carry out her sentence. For what crime, the reader does not yet know, and even after finishing the text, the reader might still wonder. A panel of magistrates, "in their great mercy and tenderness of heart," spare Hester the statutory punishment of death and sentence her instead "to stand only a space of three hours on the platform of the pillory, and then and thereafter, for the remainder of her natural life, to wear the mark of shame on her bosom" (54). The method by which society has chosen to make an example of Hester is the heaviest that man can afflict upon her, save death. Legal punishment is aimed much more 
at the protection of society than at the reformation of the offender. In other words, the punishment must serve as a deterrent from further crime. The fear of punishment must constantly keep a tight grasp on its intended objects; otherwise, it does not serve as a deterrent. A few sentences into chapter one, “The Prison-Door,” the narrator’s tone is already cynical as to the whole idea and method of punishment and the people in authority. Most tellingly, he points out that this new Utopia, from the onset, was in need of a prison: "the founders of a new colony, whatever Utopia of human virtue and happiness they might originally project, have invariably recognized it among their earliest practical necessities to allot a portion of the virgin soil as a cemetery, and another portion as the site of a prison” (41). Not only is this utopia the Puritans founded not utopian at all, it seems that the punishment devised by the magistrates, the men of law, does not have the intended outcome. The town's folk seemed outraged, of course. It is almost the entire town that has come together to witness Hester, but what they are really interested in is in learning the name of the child's father. The residents of this community are not driven in a fearfully deterred disposition by the display on the pillory, nor by Hester's gloriously embroidered A, at least not in the monumental way it was intended.

Traditional monuments are ideally placed in scenic locations like parks, museums, or galleries. However, these locations are sometimes out of the way, tucked away in locations a visitor has to travel to see and once there perhaps spend a few moments admiring it. Once the visitor leaves, the traditional monument returns to its state of solitude, and with time, it too fades from the visitor's memory. Yet, counter-monuments are designed to disrupt the public space. The creators of such counter-monuments strongly believed that it should not be "tucked away from the hard edges of urban life, 
but one more eyesore among other on a blighted cityscape” (qtd. in Young “The CounterMonument” 274). Unbeknownst to the magistrates, through their punishment, they have become complicit by placing it in the public space, as well as what would become the transformative journey for all those who come in contact with the A. Thus, the scarlet A Hester wears the very first time the readers come across its description after she steps out of the prison door almost instantly disturbs the public space:

But the point which drew all eyes, and as it were, transfigured the wearer, --so that both men and women, who has been familiarly acquainted with Hester Prynne, were now impressed as if they beheld her for the first time, --was that scarlet letter, so fantastically embroidered and illuminated upon her bosom. It had the effect of a spell, taking her out of the ordinary relations with humanity, and inclosing her in a sphere by herself. (46) The scarlet letter was thrust upon the market place and specifically Hester's bosom, an area symbolically associated with the heart and emotions. The reactions of both the market place bystanders and, if we recall, the narrator in "The Custom-House” were similar. The goal of counter-monuments is to ignite a reaction whether viewers like it or hate it. For example, in Hamburg, the city's residents complained of the inconvenience The Monument Again Fascism (1986) created, from traffic jams to the dust the construction and every subsequent lowering created. In the market place, we encounter a range of emotions. One woman regarded Hester's sewing ability: "She hath good skill at her needle, that's certain” (47). Another was indignant that Hester would embroider such a thing that was admired for its intricacy, when its aim was to cast shame on its wearer: "But did ever a woman, before this brazen hussy contrive such a way of showing it!" 
(47). And the most iron-visaged of ladies suggests that: "We stripped Madam Hester's rich gown off her dainty shoulders” (47). Yet another a young woman, states: “O, peace, neighbors, peace! Do not let her hear you! Not a stitch in that embroidered letter, but she had felt in her heart!” (47).

Some critics of counter-monuments take issue with this concept of the disruption of space. Thomas Stubblefield argues in "Do Disappearing Monuments Simply Disappear? The Counter- Monument in Revision” that these instances of the spectators' varied reactions do not necessarily preclude the kind of memory work that Young envisions. Instead, what occurs is a sense of disavowal and distraction. Yet, this is the very purpose of the counter-monument. Its goal is not to rest peacefully in commemoration and be admired with one unified voice of solidarity. If this is the result, then it is not doing its job of challenging its spectators and forcing citizens to deal with whatever the counter-monument was erected for. In chapter one, I compared Hilda and Miriam in relation to Hester. The example used was Hester, on the pillory, with her child. At this particular moment, the narrator of The Scarlet Letter shifts his view to that of an imaginary Papist: "Had there been a papist among the crowd of Puritans, he might have seen in this beautiful woman, so picturesque in her attire and mien, and with the infant at her bosom, an object to remind him of the image of Divine Maternity...” (48). The Virgin for the Puritans was neither divine nor an eternal virgin, a direct contradiction to Catholic theology; however, in Hester, an unwed mother, and Hilda, the daughter of Puritans, she stands as a representation and figure of Womanhood worthy of veneration. Here is where the comparison ends because Hilda, as one might recollect, is not a true Puritan. Hilda, as a woman, does not embody any of the qualities that can bring peace 
and prosperity to a nation. She is a being whose own selfish and hypocritical outlook shapes her gloomy end. The narrator describes Hester as having "the taint of deepest sin in the most sacred quality of life, working such effect, that the world was darker for his woman's beauty, describes Hester, on the pillory,” (48). While the passage casts her in a negative light, upon closer reading, "that the world was darker," does not mean that it was a worse place because of her. What it means is that it was not a simple, artless, utopian place anymore because of her. The world is now as it should be. Their town, their community, their identity, everything that they thought they were, is being questioned. In other words, just as Miriam's crime was the opening action for the possible, but ultimately failed transformation of Hilda, Hester, her crime, her punishment, and her child are what stand as the transformative objects of change for the members of the community. In accomplishing this, she has effectively disrupted their environment. As Young would describe it, "its aim is not to console but to provoke” (Young, "The Texture of Memory” 30).

After “The Market-Place,” Hester moves into a small cottage some distance away from the town, and in the seven years that follow, she manages to become industrious by the skill of her needlework. Just as her skills with the needle were admirable, so was Hester's kindness to the sick and poor, and her gentle nature, tenderness, and warmth. And the A, whose origin and purpose was to distinctly mark Hester as a sinner, ultimately comes to stand for Able: "The letter was the symbol of her calling. Such helpfulness was found in her, --so much power to do, and power to sympathize...they said that it mean Able; so strong was Hester Prynne, with a woman’s strength” (133-134). 
Chapter 13, rightly titled "Another View of Hester," is where we find the strongest evidence for a shift in its meaning. Hester has managed to use the punishment she was made to wear and transform it from how it was intended to be perceived. With this accomplishment, Hester has managed to alter the scarlet A. As Young argues this happens, "with audacious simplicity, the counter-monument thus flouts any number of cherished memorial conventions: its aim is not to remain fixed but to change" ("The Counter-Monument” 276). Throughout the novel, the meaning of the A changes with time. Even critics who have come to similar understandings of what the A originally meant, come to different conclusions as to what the A ultimately means. In The Story of A: The Alphabetization of America from The New England Primer to The Scarlet Letter, Patricia Crain, outlines how the question, "What does the A stand for?” has baffled critics and readers alike for many years. Richard Chase, in his book The American Novel and Its Tradition, states, "The Scarlet A is an ordinary symbol (or sign)...We can say with relative certainty what the scarlet A stands for. It stands for adultery or...it stands for the inevitable taint on all human life” (qtd. in Crain 174). Crain takes a jab at Chase by suggesting that his contortions to get the A to stand for whatever he wants leads him to suggest "tAint.” A comic note in Crain's text is nonetheless an example of the shapes and hues of Hester’s A.

In the novel, the night Governor Winthrop dies, “A great letter in the sky, --the letter A, --which we interpret to stand for Angel” appears in the sky (131). This is the town's interpretation of what they saw in the sky the night of Winthrop's death. But Dimmesdale and Hester find themselves alone in the center of town that very night, and to them who stand on the scaffold and almost face their shame together, the true meaning 
of the A is clearly revealed. To Dimmesdale, it means that he too should wear an A in shame, and the readers, who by now sympathize with Hester, associate the "Angel” with her. Even towards the end of the text, the meaning of Hester's A is challenged by the Native Americans who have come to watch the Election Day pageant: "Even the Indians were affected by a sort of cold shadow of the white man's curiosity...fastened their snake like black eyes on Hester's bosom; convinced, perhaps, that the wearer of this brilliantly embroidered badge must needs to be a personage of high dignity among her people” (202). To the Native Americans, the A is a symbol of importance.

As intricate and complex as it seems, the A is taken to mean whatever the beholder wants it to mean. This is a fundamental truth to counter-monumentalism. But some might argue, why would we not want something remembered in a static state forever? Young offers a reason. He points out that "the actual consequence of a memorial's unyielding fixedness in space is also its death over time: a fixed image created in one time and carried over into a new time suddenly appears archaic, strange, or irrelevant altogether” (“The Counter-Monument” 296). Hester’s scarlet A disperses, rather than collects, a collective memory of its meaning. As time passes, we can see that the Puritan community proves more inclined to judge Hester by the sum of her actions than are its elders, who might have the same prejudices as the community but "only fortified themselves by an iron frame work of reasoning,” rather than the feelings, emotions and reactions raised by Hester and her scarlet A (134). The disjunction between the organic ability of the community to mediate its view of the crime through appreciation of the criminal's subsequent acts and the greater intransigence of mostly aged, conservative, and male statesmen of the community is strangely similar to "The 
Custom-House” predicament. The narrator finds no purpose in working with such a disjointed group of men and in such a stagnant environment. It seems like the only people with the ability and willingness to change are the young or those who have not lost their youthful resilience. The lone voice of sympathy quoted earlier in the passage came from a spectator who is more of a peer to Hester. She shares the circumstances of youth and motherhood and seems a fitter judge than the patriarchs who assemble, give out, and witness her punishment. They are removed from Hester in age and gender and passionless rigidity, like the old-corrupt custom officials. However, the town's people, high and low, employ Hester for her skillful and artful works with the needle. Just as the act of choice by the narrator of "The Custom-House" is taking writing back up after a period of inactivity, this is the town's people active partaking of their own free will in crafting the meaning of the A and by extension their own community's identity.

Hilda from The Marble Faun and Arthur Dimmesdale from The Scarlet Letter are religious parallels: Hilda, the daughter of Puritans, and Reverend Dimmesdale, the leader of the Puritan flock. These two characters serve as representations of the kinds of citizens believed to be ruining the nation. Hester naturally does suffer because of her circumstances. After all, she is a single mother having to support her child, but compared to the plight of her accomplice, Arthur Dimmesdale, who keeps and maintains his rank and status as the community's religious leader, Hester's plight might come off as relatively easy. Hester fares much better than Dimmesdale for the same reason Miriam ultimately triumphs over Hilda. Dimmesdale is the character most devastated by his role in the crime as co-adulterer, and like Hilda, he suffers. For seven years, he has steadily and slowly withered from the young, strong man he once was: "His form grew 
emancipated; his voice, though still rich and sweet, had a certain melancholy prophecy of decay in it; he was often observed, on any slight alarm or other sudden accident, to put his hand over his heart, with first a flush and then a paleness, indicative of pain” (100). His unflinching faith is cause enough for Dimmesdale's torment, but other factors compound his misery.

It is true that he has sinned according to his own system of beliefs, but he does not dilute or tailor his belief system to accommodate what he has done, unlike Hilda who is tempted by Catholicism even before her person is stained and who seeks solace in Catholicism afterwards. Dimmesdale does not budge. Although he flagellates himself, he cannot allow himself to borrow another means of contrition from the Catholic faith, namely, confession. Dimmesdale seems to be happy and willing to suffer and wither away in pain and solitary repentance, so much so that in a heated discussion with Chillingworth regarding his state of health, Dimmesdale almost shouts, "But who art thou, that meddlest in this matter? --- that dares thrust himself between the sufferer and his God?” (113). When Hester meets him in the forest to divulge Chillingworth's identity, Dimmesdale justifies his failure to confess his crime: "Of penance I have had enough! Of penitence there has been none! Else, I should long ago have thrown off these garments of mock holiness, and have shown myself to mankind as they will see me at the judgment-seat” (159). However, Dimmesdale immediately contradicts himself by relating his misery to the concealment of his crime, something that he should embrace according to his belief system: "Happy are you, Hester, that wear that scarlet letter openly on your bosom! Mine burns in secret. Thou little knowest what a relief it is, after the torment of a seven years cheat, to look into the eye that recognizes me for what I am!” (159). In 
chapter seventeen, “The Pastor and His Parishioner," the reader is privy to the internal turmoil of Dimmesdale, very similar to Hilda’s in “The World’s Cathedral”. Indeed the reader is privy to the internal turmoil of all self-described Puritans who identify with sin rather than with salvation, for to be a Puritan, one must believe in one's innate depravity. Yet, Dimmesdale, almost every time he appears on the page, contradicts himself when he speaks and acts, contrary to Hilda who without much steering willingly goes to confess, albeit for her own self-regarding needs.

At times Dimmesdale wishes he could openly confesses his crime, even though he has had many opportunities to do so. There is an opportunity as early as "The MarketPlace” chapter when he is asked to help coax the truth out of Hester. He attempts a halfhearted confession the night of Governor's Winthrop's death when he stands on the pillory and utters a cry in the middle of the night truly expecting the town's people to leave their beds and explore the source of the sound. It is in the woods that Dimmesdale seems to talk himself into at last confessing his crime. Finally, it looks like Dimmesdale will take his place upon the scaffold and face his shame like Hester has done for the last seven years. Yet, not surprisingly, like Hilda, whose confession and ultimate rejection of her once good friend rests not on moral duty, but in personal, selfish desire to preserve her own peace of mind and perceived purity at the expense of her friend, Dimmesdale resolves to confess only after delivering the most inspired sermon of his career, the Election Sermon, thus postponing his spiritual salvation so as not to interfere with the climax of his professional career. Dimmesdale's preoccupation with his status in the community means he shares the same hypocrisy and unrelenting selfishness as Hilda. Dimmesdale, like Hilda, cares more about his social reputation than anything else. His 
health, his peace, his self-respect, his love, his soul — all may go. Only his reputation should remain. And yet it is that selfsame false reputation that daily causes him the keenest anguish of all. On Election Sunday, after he preaches his last sermon, Dimmesdale proceeds to the pillory and confesses to his congregation, the residents of Boston, the extent of his guilt.

Readers might assume it was the mark of his sin on his chest, a letter A, that was bared when Dimmesdale rips open his shirt, but the narrator actually does not say what was revealed: "With a convulsive motion he tore away the ministerial band from his breast. It was revealed! But it were irreverent to describe that revelation” (209). One might deduce that by using "irreverent" to describe what was on Dimmesdale's breast, the narrator sought to avoid disrespecting the reader by saving him or her the description of something gruesome. However, I see this word choice on behalf of the narrator not as an attempt to spare the reader "who will fling aside his volume" from the impudent or flippant observation that Reverent Arthur Dimmesdale is false. The choice of word is for "the few who will understand him better than most," the few who see Dimmesdale for the fraud he is. Fainting to the wooden floor of the scaffold, Dimmesdale dies, but not before telling Hester that they might meet again in Heaven thanks to God's proven mercy, “most of all, in [his] afflictions” (210). Reverend Dimmesdale goes on to list all the suffering he has been through, but thanks God for allowing him to "to die this death of triumphant ignominy before the people!” (210). Perhaps if Dimmesdale had no illusions as to the destination of his soul like Young Goodman Brown, as a character he could redeem himself at his last moment. But even with his last dying breath, Dimmesdale cannot be genuine. 
How does Dimmesdale and Hilda figure into the argument of national identity? Reverend Arthur Dimmesdale is the leader of a congregation. In his capacity, he is empowered as a role model for how the character of the nation should be constructed. If we believe Dimmesdale is the image of all that is virtuous and noble, then we should model our moral compass after his. What Hawthorne is trying to tell us is that individuals like Dimmesdale embody everything that is wrong with America. Hilda, in a matriarchal role, as argued in the previous chapter in reference to what Barbara Welter calls, "The Cult of True Womanhood 1820-1860," is charged with what some would argue is the most important task of nation building and identity formation. We can assume she and Kenyon will go off and produce offspring that share their own stiff view of what America should be. However, what Hawthorne gives us are characters who fail miserably at life. Dimmesdale is dead, and Hilda and Kenyon are homeless. What better end is there for characters that are rotting the nation at its core? But Hawthorne does provide characters who embody the type of person the nation needs. Through Pearl, a child of defiance and passion, we learn just what individual, and better yet, woman, the nation needs.

While the community is actively engaging in forming their own identity through the transformative power of Hester and the scarlet letter, Pearl is the most vital character of The Scarlet Letter. Hester names her daughter Pearl, "not as a name expressive of her aspect, which had nothing of the calm, white, unimpassioned lustre that would be indicated by the comparison. But she named the infant 'Pearl,' as being of great pricepurchased with all she had—her mother's only treasure!” (74). The physical result of free and wild passion comes to represent, in her person, the very notion of change. Pearl is the scarlet letter embodied. Pearl is, technically, “American” born, having been born in what 
would become the state of Massachusetts and eventually the U.S. As such, due to the circumstances of her birth, she is the embodiment of what Americanness should be about: transformation, change, resilience, and inquisitiveness. While in The Marble Faun Miriam is the most unlikely to be viewed as American, her characteristic as a possible mulatta on the eve of the Civil War, and the fact that she is born out of sin similarly to Pearl, means she too embodies the representation of a new type of citizen, a new person that should be welcomed in the community. Her hybridity, her bi-racialness, indicative of transformation, is what makes her irrepressible. She is change in the flesh.

Anyone would have found Pearl an encumbrance, after all she is a child born out of wedlock. Perhaps the community thinks of her as an encumbrance because no one seems to know exactly what she is, not even her mother: "Hester could not help questioning at such moments, whether Pearl was a human child. She seemed rather an airy sprite” (76). In fact, everyone who comes in contact with Pearl has this same impression. She is a new and different creature, unlike anyone they have ever encountered. She is an "other". So they take to calling her names of mythical, magical or fantastical creatures like "the elf child,” "demon offspring,” and "little elf.” Perhaps Hawthorne wished to convey the small-mindedness and senseless superstition of the Puritans, but in reality other characters try to define her as a "little elf" precisely because they have no other means of verbalizing what she is, because they do not identify with her or what she represents.

Pearl, as a character, could have been restricted to simple appearances, her utterances to monosyllables or sentimental commonplaces. Not only is she free from repression of this kind, but also she asserts herself as the most vivid and active figure in 
the story. Instead of keeping tragically and pitifully in the background, as a guiltless unfortunate whose life was ruined before it began, this strange little being, with laughing defiance of precedent and propriety, takes the reins in her own childish hands and dominates every one with whom she comes in contact:

Her nature appeared to possess depth, too, as well as variety; but—or else Hester's fears deceived her—it lacked reference and adaptation to the world into which she was born. The child could not be made amenable to rules. In giving her existence a great law had been broken; and the result was a being whose elements were perhaps beautiful and brilliant, but all in disorder, or with an order peculiar to themselves, amidst which the point of variety and arrangement was difficult or impossible to be discovered.

Hester "felt like one who evoked a spirit, but, by some irregularity in the process of conjuration, has failed to win the master-word that should control this new and incomprehensible intelligence” (77). Pearl instinctively comprehends her position as a born outcast from the world of christened infants; however, her defiance of how the community would categorize her is her lifeblood. She is aware that to accept the Puritans' opinion they have of her and her mother would be to deny her right to exist. She rejects their estimation as though her life depended on it because it does. To the Puritan leaders, she is only redeemable through austere and strict training that will eliminate any trace of her spontaneity. They wish to take her from Hester "and clad soberly, and disciplined strictly, and instructed in the truths of heaven and earth" (92). Puritan training is a washing clean of this transformative quality of hers and a re-appropriation into the static 
community the leaders wish to maintain. Governor Bellingham as well as other leaders of the community are fearful of Pearl, so much so that to them she is a "half-fledge angel of judgment," sent to punish them for their sins (85).

Actively standing as the personification, instead of the victim of a sin, Pearl affords a unique opportunity for casting light upon the central nature of the sin itself. Pearl, as we are frequently reminded, is the scarlet letter made alive. She is capable of being loved and gifted with a manifold power of retribution for sin. The principle of her being is the freedom of a broken law; she is developed, "a lovely and immortal flower, out of the rank of luxuriance of a guilty passion,” yet also irresponsible and independent as if distinctions of right or wrong did not exist in her (76).

Pearl is often associated with light, especially in the forest scene, where "she did catch the sunshade, and stood laughing in the midst of it” (152). This is indicative of her natural goodness and ability to heal. She brightens her mother's outlook, and Hester begins to think of her as a redemptive force: "Might it not be her errand to soothe away the sorrow that lay cold in her mother's heart, and cover it into a tomb?” (149). Her relationship with nature coincides with the relationship she is creating with the Puritan community, and just as the community cannot control nature, wild and free, it will not be able to control Pearl, either. Although those in charge have succeeded in controlling Hester, she cannot bring herself to quell her daughter's wild spirit. It seems the Puritan leaders are coming to the realization of Pearl's power and their inability to do something about it. Pearl is not there to atone for their individual sins, but to atone for the nation and what it means to be an “American” with her person. For Cindy Lou Daniels, in her essay "Hawthorne's Pearl: Woman-child of the Future,” Pearl is a feminist prototype who 
“demonstrates a new type of woman—one capable of answering whatever needs society may have” (226). I agree with Daniels' feminist argument that Pearl, in all her symbolic presentations, is the character that demonstrates the changing role of the female that began in the nineteenth century. As an extension of the argument made earlier that Hawthorne's seventeenth century setting is indicative of real world nineteenth century issues, juxtapose with the idea of nation building, identity and what that identity should be, then we have to look at Pearl and Miriam as female prototypes. Through Miriam, we can conclude that the evil of slavery can be erased if we choose to erase it and build a new inclusive nation with citizens like Miriam and Pearl that represent this "otherness."

Throughout much of the novel, Pearl is a child. The day Dimmesdale dies she is but a girl of seven. On Election Day, when she steps boldly forth and kisses her father's lips, "as her tears fell upon her father's cheek, they were the pledge that she would grow up amid human joy and sorrow, nor forever do battle with the world, but be a woman in it” (209). That is the last we actually hear from Pearl. At this point, it is certain Pearl will grow up and become a woman in the world based on how she has been crafted in the story. Pearl will not swiftly or abruptly fall back into the Puritan characterization of a "good" woman or a "good" citizen; she will take charge and remain in charge, as she was created to do.

Tellingly, in the end, Hawthorne writes of the mystery of Pearl in terms of the future. Old Roger Chillingworth by his last will and testament left little Pearl "a very considerable amount of property, both in [America] and in England...so, the elf child, the demon offspring...became the richest heiress of her day, in the New World" (213). When Pearl reaches a marriageable age, the narrator tells us that she and the "wearer of the 
scarlet letter" disappeared, "for many years...though a vague report would now and then find its way across the sea," until one day Hester Prynne returned, alone. But what of Pearl? "If still alive, she must now have been in the flush and bloom of early womanhood," and there were some who faithfully believed "Pearl was not only alive, but married, and happy, and mindful of her mother"; however, "none knew— nor ever learned, with the fullness of perfect certainty" what became of Pearl (213-214). By giving Pearl a future, Hawthorne accomplishes two things. One, he avoids a sentimental, tragic ending in order to add power to the development of Pearl. She is not to be regarded as a symbol created to be simply cast aside. Two, if we adhere to Daniels' argument, we agree that Hawthorne suggests that there is the possibility of a future for all women.

There is something more here than Pearl living the life she deserves. Why does she not live this life in America? If Pearl is the new American woman embodied, why does she stay abroad, in Europe somewhere, perhaps England? We might look to Miriam and Hilda for answers. We know that Hilda will forever be nationless. Yes, she is American, as much a daughter of the Puritans as Pearl is, but she does not fit in anywhere. There is no place for Hilda in the New World, nor abroad. That is why she and Kenyon are bound to float in the Atlantic space. Miriam, we know, leaves the U.S. and moves to Rome because she is escaping a past that is haunting. However, Miriam, at the end of The Marble Faun, fares much better than Hilda. She is in a place where, having cast off her past and burden, she is now free to be who she is. Will she ever return to America? Perhaps, and maybe Pearl will too one day. But the fact that both characters have demonstrated what an inclusive and progressive nation needs and chose not to live in it is a direct message to the nation that the best of citizens would rather live elsewhere. 
The nation is losing its most precious assets. These individuals that physically embody and represent change are the most likely to help bring about the nation's countermonuments. However, they refuse to live in a community that does not value them and marginalizes them, a community that would rather count amongst its citizens people like Hilda and Dimmesdale, as corrupt, selfish and hypocritical as they are.

Let us return our attention to Hester and the scarlet letter. Perhaps one of the most difficult aspects of Young's theory to comprehend is the disappearing countermonument. One might assume that even though theoretically these counter-monuments stand for something different from traditional monuments, they would at least resemble traditional monuments in their composition. Stone, marble, granite— these are natural elements known for their beauty and lasting qualities. Typically, the material chosen for a monument is selected for its strength and its ability to endure the test of time. What does this say about how we choose to commemorate our collective memory? And whose job is it really to do the remembering? Those who believe in counter-monuments say it is our job. To Young, "time mocks the rigidity of monuments, the presumptuous claim that in its materiality, a monument can be regarded as eternally true, a fixed star in the constellation of memory” (“The Counter-Monument” 294). Young's statement is paradox. How so? Some counter-monuments do not start out as such. Others are accidental, and some counter-monuments are not meant to last. This was the fate of the Gerzes’ Monument Against Fascism (1986). In the time span of a few years, the monument would slowly be lowered into the ground until it eventually disappeared. The only memory of its existence is a plaque where it once stood and the photographs. "Why bury it?” many would ask. "What's the purpose?” For the Gerzes, “once the art object 
stimulates in the viewer a particular complex of ideas, emotions, and responses that then come to exist in the viewer independently of further contact with the piece of art, it can wither away, its task accomplished” (qtd. in Young, "The Counter-Monument” 278). The Gerzes' hope is that we internalize these memorials and have them become a perpetual memory; thus, the burden and duty of remembrance is given back to the people. In the case of the scarlet letter, our counter-monument, what we have left as Hawthorne describes in "The Custom-House" Preface is a "relic" and almost instantly imparts "a deep meaning in it, almost worthy of interpretation” (28). Hawthorne experienced the memory of an absent monument. The tarred letter A is not the memorial; instead, it has become an invitation for the discoverer to search what it means to them in their minds and possibly their hearts. As a result, the ultimate goal of the counter-monument has been achieved. The burden of memory has been returned to the people, and Hawthorne, or narrator in the Custom House, took up this burden and gave the people of his time this tale.

And what of Hester? Why does she choose to return to America? Hawthorne has Hester Prynne return to America because the transformative powers of the scarlet A, and Hester herself must be allowed to continue to do their work where it is needed most. The scarlet A “never after did it quit her bosom” (215). Hester and her scarlet A do indeed continue to transform all those they come across: "People brought all their sorrows and perplexities, and besought her consul, as one who has herself gone through a mighty trouble” (215). In this manner, as a guiding friend and helper to people marginalized and wronged by members of their own communities for their sin or "otherness," she lived for many years. She assured the members of the community that it was her "firm belief, that, 
at some brighter period, when the world should have grown ripe for it, in Heaven's own time, a new truth would be revealed” (215). Hester prophetically envisions a country that will have to struggle to survive, a nation that will have to assess itself constantly in order to grow and prosper. Once its leaders and citizens realize that in order to survive, they must adapt, “a new truth would be revealed.” A new way of life that ensures the longevity of the nation.

Yet, readers of The Scarlet Letter are left with perhaps an image that is considered and identified as a monument: the tombstone. It is the archetypal form of American art and customarily the chief channel of sculptural art for Puritan New England (Fernie). The last pages are dedicated to Hester’s legacy and her place of rest, the burial ground beside the King's Chapel, where she and Dimmesdale will reside for eternity side by side. What is it about tombstones that call out, "Monument”? Is it because their duty is remembrance, and they are built of symbolically lasting stone? Possibly. But as Crain argues in her book The Story of A, "Hawthorne (as Harold Bloom has said of Dickinson) makes the visible very hard to see” (199). In fact, Hester’s grave and tombstone are all but disappeared. In the novel's last lines Hawthorne writes:

All around, there were monuments carved with armorial bearing; and on this simple slab of slate—as curious investigator may still discern, and perplex himself with the purport — there appeared the semblance of an engraved escutcheon. It bore a device, a herald’s wording of which might serve for a motto and a brief description of out now concluded legend; so somber is it, and relieved only by one ever-glowing point of light gloomier 
than the shadow: — “ON A FIELD, SABLE, THE LETTER A, GULES”’.(215-216)

Only a careful and alert visitor to the burial ground next to the King's Chapel might be able to discern "the semblance of an engraved escutcheon". Similarly to the relic that is the letter A Hawthorne finds early on in the text, the tombstone is all but lost. The tombstone, rather than serve the purpose of remembrance serves purely as a marker, the illusion of memory. Hester's tombstone is not, as the Gerzes’ would argue, “an enormous pedestal with something on it presuming to tell people what they aught to think" (qtd. in Young “The Counter-Monument” 274). Remembrance of a loved one is not entrusted to a tombstone inscribed with an epitaph, whose sole purpose is to try to sum up the life of someone in a few words. Rather, it is entrusted to individuals who have internalized the memory and endeavor to keep it alive, in fact, to the Gerzes', the best monument “may be no monument at all, but only the memory of an absent monument” (qtd. in Young “The Counter-Monument” 279). As such, even in death, Hester’s final resting place, with its vanishing marker, continues to serve as a counter-monument for memory. It seems that the narrator of "The Custom-House” need not worry that his tale nor the characters of his imagination "would take neither the glow of passion not the tenderness of sentiment, but retained all the rigidity of dead corpses” (30). The Scarlet Letter, with relative ease, has imprinted itself on our memories and accomplished what Young would argue is the most difficult aspect of the counter-monument, which is "to stimulate memory no less than the everlasting memorial, but by pointing explicitly at its own changing face,” and The Scarlet Letter does exactly this. (“The Counter-Monument” 295). 


\section{CLOSING}

What is the nature of human history? What power does the past hold over the present and the future? Can the United States overthrow its European heritage and build a new one? Is that endeavor futile? Can and will the United States come to understand that change is inevitable and that we have no power over it? It is strange how these questions seem to have a place in the twenty first century as well as the nineteenth. Or is it? For Hawthorne, a man of the nineteenth-century who was still being haunted by the actions of his forefathers two hundred years before, he might not find them so strange.

If we pick up where Hawthorne left off at the conclusion of The Marble Faun in 1860, we realize that his warning could not have come sooner. Within months, Abraham Lincoln was elected president, and by December of 1860, South Carolina seceded from the Union followed by Mississippi, Florida, Alabama, Georgia, Louisiana and Texas. In February of 1861, the Confederate States of America was formed with Jefferson Davis as president. On April 12, 1861, the first shots were fired, and the Civil War began. A divided and ultimately broken U.S. is the aftermath. By the war's end, two percent of the United States population was dead because a section of its citizenry would do practically anything to protect, and expand, the right to own other people. Except it lies not simply with the right to own others, but with the notion that this group of people, if they had willingly abolished slavery, would now have to look at the person they just owned as a fellow citizen and therefore visualize a shared national identity with an ethnic "other".

What about the religious "other”? While Protestantism even today is still the religion of the white elite, as the nineteenth century progressed, the Puritan zeal began to lose its power. For example, the worship ban of the Virgin Mary slowly was abandoned. 
Several of America's prominent Protestant families declared greater interest in the biblical role and image of the Virgin, some to the extent of reverence. The Beechers, and in particular Harriett Beecher (it is important to point out that the Beechers were also abolitionists), in her attribution of the Virgin to some of her female characters for example, is evidence that at least on the subject of religion the nation was becoming more tolerant. This might have been an easier achievement since most European immigrants were Catholic or subscribed to a form of Christianity, so absorption into an already Christian, White, American identity happened more smoothly.

In terms of commemoration and monuments, it is safe to say that the U.S. did not heed John Quincy Adams' remark on the House floor. One look at our nation's capital and we are overwhelmed by monuments and memorials of people, wars, and national tragedies. The Washington Monument, after a few interruptions due to lack of funds and the American Civil War, was eventually completed in 1888 . However, since those early years of the republic when John Quincy Adams served as the living memory of why democracy has no monuments, the nation's view on monuments and their vision of the nation have changed.

Throughout the twentieth-century, memorials continued to gradually transform from the standard sculptural projects into more complex projects as well as into different spaces, often within museums or galleries. But all these commemorative practices come together more powerfully around the remembrance of war. One contemporary war memorial that echoes James Young's suggestion as to the role of monuments is he Vietnam Veterans Memorial, which deliberately encourages multiple meanings and uses. John Bodnar, in Remaking America: Public Memory, Commemoration, and Patriotism in 
the Twentieth Century, argues that the success of the Vietnam Veterans Memorial is due to the interwoven "official” as well as the "vernacular" memory. The memorial allows for an official state memory, while also maintaining a vernacular memory driven by ordinary people who have the right to voice their own social and political concerns of the present. The Vietnam Veterans Memorial comprises the same ability as Hester’s A. The same way the memorial can take on different meanings, so too does the A change from adultery, to able, and finally, to angel. Likewise, they both hold the power to disrupt public space.

I think the answer to some of these issues might lie in Pierre Nora's three-volume text, Realms of Memory. Nora argues that modern societies invest so much time, money, and effort in memory sites because these have replaced or forgotten real environments of memory. Nora’s argument echoes the anti-monument rhetoric of early republicans like Adams. Nora suspects that modern commemoration was invented to make up for a lack of organic unity, a natural expression of the bonds within a community of modern nations and societies. In simple words, we are a society lacking a natural sense of belonging and solidarity.

If we look to Hawthorne for an answer, he will say the choice was ours, an active choice to forget real environments of memory and replace them with artificial ones that hold no sense of belonging, only a static message or meaning. Are we too late to mend our decision? By the look of the current state of political and social affairs in the U.S. and around the world, a pessimist might say we might be. If we truly are, then, the outcome is sketched out for us in the works of Hawthorne. We will deteriorate and collapse as a nation. The only way to prevent this tragedy is to embrace the qualities of counter- 
monuments. Only then will we find the pathway of how to live in the twenty-first century where change is as fast and certain as the forgetfulness of an individual and a society of any and all monuments.

\section{REFERENCES}

Allen, William C. History of the United States Capitol: A Chronicle of Design, Construction, and Politics. Washington, DC: U.S. GPO, 2001. Print. 
Byrne, Julie. "Roman Catholics and Immigration in Nineteenth-Century America.” National Humanities Center. National Humanities Center, 2000. Web.

Byer, Robert H. "Words, Monuments, Beholders: The Visual Arts in Hawthorne's The Marble Faun.” American Iconology: New Approaches to Nineteenth-century Art and Literature. Ed. David C. Miller. New Haven: Yale UP, 1993. Print.

Blight, David W. Race and Reunion: The Civil War in American Memory. Cambridge: Belknap of Harvard UP, 2002. Print.

Bodnar, John E. Remaking America: Public Memory, Commemoration, and Patriotism in the Twentieth Century. Princeton, NJ: Princeton UP, 1992. Print.

Crain, Patricia. The Story of A: The Alphabetization of America from the New England Primer to The Scarlet Letter. Stanford, CA: Stanford UP, 2000.

Daniels, Cindy Lou. "Hawthorne's Pearl: Woman-Child of the Future.” ATQ (The American Transcendental Quarterly) 19.3 (2005): 221-35. Academic Search Complete. Web. 20 Mar. 2015.

Emerson, Ralph W. “Self-Reliance.” Emerson Central. Emerson Central, 09 Mar. 2009. Web. 23 Mar. 2015.

Fernie, Deanna. Hawthorne, Sculpture, and the Question of American Art. Surrey, England: Ashgate Limited, 2011. Print.

Greenwald, Elissa. "Hawthorne and Judaism: Otherness and Identity in The Marble Faun.” Studies in the Novel 23.1 (1991): 128-37. JSTOR. Web.

Halbwachs, Maurice. On Collective Memory. Ed. Lewis A. Coser. Chicago: University of Chicago, 1992. Print.

Hawthorne, Nathaniel. "Chiefly About War Matters.” The Atlantic. Atlantic Media Company, 1 July 1862. Web. 02 Feb. 2015.

---. The Marble Faun. Mineola, NY: Dover Publications, 2004. Print.

---. The Scarlet Letter. Ed. Nancy Stade and George Stade. New York: Barnes \& Noble Classics, 2003. Print.

---. The House of the Seven Gables. Google Books. Google. Web.

---. “Preface to the Second Edition.” Preface. The Scarlet Letter. Ed. Nancy Stade and George Stade. New York: Barnes \& Noble Classics, 2003. 3. Print.

---. “The Custom-House.” Introduction. The Scarlet Letter. Ed. Nancy Stade and George 
Stade. New York: Barnes \& Noble Classics, 2003. 5-39. Print.

Hoeveler, Diane Long. "Beatrice Cenci in Hawthorne, Melville and Her Atlantic-Rim Contexts."Romanticism and Victorianism on the Net 38-39 (2005). Marquette University E-Publications. Marquette University. Web.

Kemp, Mark A.R. “The Marble Faun and American Postcolonial Ambivalence.” Modern Fiction Notes 43.1 (1997): 209-36. JSTOR. Web.

Knobel, Dale T. Paddy and the Republic: Ethnicity and Nationality in Antebellum America. Middletown, CT: Wesleyan UP, 1986. Print.

Mellow, James R. Nathaniel Hawthorne in His times. Boston: Houghton Mifflin, 1980. 415. Print.

"Monument." Oxford English Dictionary. Oxford University Press. Web.

Nora, Pierre, and Lawrence D. Kritzman, eds. Realms of Memory: Rethinking the French past. New York: Columbia UP, 1996. Print.

Person, Leland S. The Cambridge Introduction to Nathaniel Hawthorne. Cambridge: Cambridge UP, 2007. Print.

Raimon, Eve Allegra. The Tragic Mulatta Revisited: Race and Nationalism in Nineteenth-century Antislavery Fiction. New Brunswick, NJ: Rutgers UP, 2004. Print.

Roy, Arundhati. The God of Small Things. New York: Random House, 2008. Print.

Said, Edward W. Culture and Imperialism. New York: Vintage, 1994. Print.

Savage, Kirk. Monument Wars: Washington, D.C., the National Mall, and the Transformation of the Memorial Landscape. Berkeley: University of California, 2009. Print.

Schiller, Emily. "The Choice of Innocence: Hilda in The Marble Faun.” Studies in the Novel 26.4 (1994): 372-81. JSTOR. Web.

Stubblefield, Thomas. "Do Disappearing Monuments Simply Disappear?: The CounterMonument in Revision.” Future Anterior: Journal of Historic Preservation History. Theory, and Criticism, Vol. 8, No. 2 (2011): 1-11. JSTOR. Web. 25 Apr. 2015.

Tellefsen, Blythe Ann. ““'The Case with My Dear Native Land”: Nathaniel Hawthorne’s Vision of America in The Marble Faun.” Nineteenth-Century Literature 54.4 (2000): 455-79. JSTOR. Web. 
Welter, Barbara. “The Cult of True Womanhood: 1820-1860.” American Quarterly 18.2 (1966): 151-74. JSTOR. Web.

Wineapple, Brenda. Hawthorne: A Life. New York: Random House, 2004. Print.

Young, James E. "The Counter-Monument: Memory against Itself in Germany Today.” Critical Inquiry 18.2 (1992): 267-96. JSTOR. Web.

---. “The Texture of Memory.” The Texture of Memory: Holocaust Memorials and Meaning. New Haven: Yale UP, 1993. Print. 